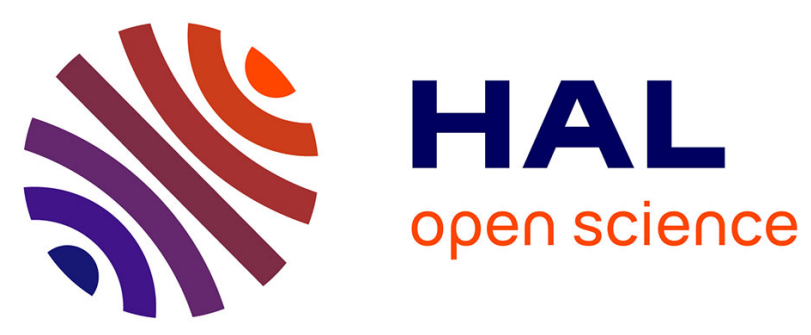

\title{
Sequencing viral siRNAs to identify previously undescribed viruses and viroids in a panel of ornamental plant samples structured as a matrix of pools
}

Eric Verdin, Catherine Wipf-Scheibel, Patrick Gognalons, François Aller, Mireille Jacquemond, Mark Tepfer

\section{To cite this version:}

Eric Verdin, Catherine Wipf-Scheibel, Patrick Gognalons, François Aller, Mireille Jacquemond, et al.. Sequencing viral siRNAs to identify previously undescribed viruses and viroids in a panel of ornamental plant samples structured as a matrix of pools. Virus Research, 2017, 241, pp.19-28. 10.1016/j.virusres.2017.05.019 . hal-01607064

\section{HAL Id: hal-01607064 \\ https://hal.science/hal-01607064}

Submitted on 26 May 2020

HAL is a multi-disciplinary open access archive for the deposit and dissemination of scientific research documents, whether they are published or not. The documents may come from teaching and research institutions in France or abroad, or from public or private research centers.
L'archive ouverte pluridisciplinaire HAL, est destinée au dépôt et à la diffusion de documents scientifiques de niveau recherche, publiés ou non, émanant des établissements d'enseignement et de recherche français ou étrangers, des laboratoires publics ou privés.

\section{(ㅇ)(1) $\$$}

Distributed under a Creative Commons Attribution - NonCommercial - NoDerivatives| 4.0 


\section{Accepted Manuscript}

Title: Sequencing Viral siRNAs to Identify Previously Undescribed Viruses and Viroids in a Panel of Ornamental Plant Samples Structured as a Matrix of Pools

Authors: Eric Verdin, Catherine Wipf-Scheibel, Patrick

Gognalons, François Aller, Mireille Jacquemond, Mark Tepfer

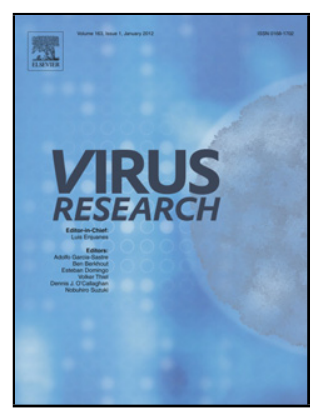

PII: S0168-1702(16)30788-2

DOI: http://dx.doi.org/doi:10.1016/j.virusres.2017.05.019

Reference: VIRUS 97147

To appear in: $\quad$ Virus Research

Received date: $\quad 30-11-2016$

Revised date: $\quad 12-5-2017$

Accepted date: $\quad$ 24-5-2017

Please cite this article as: Verdin, Eric, Wipf-Scheibel, Catherine, Gognalons, Patrick, Aller, François, Jacquemond, Mireille, Tepfer, Mark, Sequencing Viral siRNAs to Identify Previously Undescribed Viruses and Viroids in a Panel of Ornamental Plant Samples Structured as a Matrix of Pools.Virus Research http://dx.doi.org/10.1016/j.virusres.2017.05.019

This is a PDF file of an unedited manuscript that has been accepted for publication. As a service to our customers we are providing this early version of the manuscript. The manuscript will undergo copyediting, typesetting, and review of the resulting proof before it is published in its final form. Please note that during the production process errors may be discovered which could affect the content, and all legal disclaimers that apply to the journal pertain. 
Sequencing Viral siRNAs to Identify Previously Undescribed Viruses and Viroids in a Panel of Ornamental Plant Samples Structured as a Matrix of Pools

Short title: Sequencing viral siRNAs to identify new viruses and viroids in ornamental plants

Eric Verdin ${ }^{\text {a, }}$, Catherine Wipf-Scheibel a, Patrick Gognalons a, François Aller ${ }^{\text {b }}$, Mireille Jacquemond $^{\text {a, }}+$, Mark Tepfer ${ }^{a, c, *}$

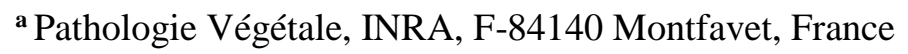

${ }^{\mathbf{b}}$ Fasteris SA, Ch. du Pont-du-Centenaire 109, CH-1228 Plan-les-Ouates, Switzerland

${ }^{\mathbf{c}}$ Institut Jean-Pierre Bourgin (IJPB), INRA, AgroParisTech, CNRS, Saclay Plant Sciences (SPS), Université Paris-Saclay, F-78026 Versailles, France.

* Corresponding authors

E-mail: Eric.Verdin@inra.fr, Mark.Tepfer@inra.fr 


\title{
Highlights
}

- Deep sequencing of siRNAs allowed de novo assembly of contigs to identify viruses

- Samples could be pooled before deep sequencing without loss of virus detection

- Detection of 27 previously unknown viruses, including all types of viral genomes

- Ornamental sector could be the source of novel plant diseases in all types of crops

\begin{abstract}
Ornamental plants constitute a largely unknown and potentially important source of pathogens affecting not only ornamental plants, but also major crop species. We have carried out studies using high-throughput sequencing of 21-24 nt RNAs from potentially virus-infected ornamental plants, followed by assembly of sequence scaffolds, to identify the virus and viroid genomes present in a panel of 67 plant samples representing 46 species belonging to the main sectors of the ornamental plant industry (cut flowers, pot plants, bulbs). A pilot study demonstrated that samples could be pooled ( 5 samples per pool), and the overall process simplified without loss of detection of important known pathogens. In a full-scale study, pools of 5 samples were organized in a $5 \times 5$ matrix to facilitate attribution of a sequence to a precise sample directly from analysis of the matrix. In the total of 67 samples analyzed in the two studies, partial sequences suggesting the presence of 25 previously unknown viruses and viroids were detected, including all types of virus and viroid genomes, and also showed four cases of known viruses infecting previously undescribed hosts. Furthermore, two types of potential mis-assembly were analyzed, and were shown to not affect the conclusions regarding the presence of the pathogens identified, but show that mis-assembly can affect the results when the objective is determining complete bona fide viral genome sequences. These results clearly confirm that ornamental plants constitute a potential source of unknown viruses and viroids that could have a major impact on agriculture, and that sequencing siRNAs of potentially virus- or viroid-infected ornamental plants is an effective means for screening for the presence of potentially important pathogens.
\end{abstract}

Keywords: Next-generation sequencing, siRNA, virus, viroid, ornamental plant

\section{Introduction}

Over the past decades, globalization of the ornamental plant industry has brought major changes, including ever increasing numbers of ornamental species, their rapid turnover, and a massive increase 
the scope of trade worldwide, which could lead to more severe epidemiological risks due to virus and viroid diseases of ornamentals. The potential seriousness of the impact of ornamental plants harboring viruses and viroids was clearly demonstrated when a serious quarantine pathogen of potato and tomato, Potato spindle tuber viroid (PSTVd), was observed in numerous asymptomatic plants of the widely grown ornamental species Solanum jasminoides, first in the Netherlands (Anonymous 2006a, Anonymous 2006b, Anonymous 2006c), then in Italy (Di Serio 2007). Thus, the presence of known and unknown viruses and viroids in ornamental plants has a clear potential for being the unsuspected source of major pathogens of crop species.

Over the past decade, advances in next-generation sequencing have constituted a major breakthrough in plant virology (see Roossinck et al., 2015, and Wu et al., 2015 for review). In particular, all three of the most used strategies (sequencing double-stranded RNA, sequencing the nucleic acids of extracts enriched in virus-like particles, and sequencing virus-derived 21-24 nt siRNAs), have made it possible to detect previously unknown viruses at a remarkable scale, and appropriately these strategies are being considered for inclusion in quarantine measures (Martin et al., 2016) Although each strategy has a clear bias in the types of pathogens detected, siRNA sequencing has the advantage of detecting all types of viral genomes as well as viroids, although double-stranded RNA viruses may be underrepresented (Roossinck et al., 2015). These strategies have been widely used to determine the sequence of numerous viruses of crop plants, and have provided a unique view of the diversity of viruses present in natural environments at an ecosystem scale (Roossinck et al., 2015), but to the best of our knowledge they have never been applied to a broad-scope evaluation of the presence of viruses and viroids in ornamental plants.

We have thus carried out a study testing the feasibility of using siRNA sequencing to detect viral and viroid genomes in ornamental plants. We present here a study of 67 samples coming from a total of 46 plant species, most of which expressed possible symptoms of disease. They were from a variety of sources, including producers of ornamental plants and the national wholesale ornamental plant market at Rungis, France. In addition to providing a first, very preliminary global look at the viruses and viroids present in ornamental plants, the experiments were designed to explore various means to simplify protocols and reduce costs, including pooling samples and analyzing pools in a matrix. More than $75 \%$ of the samples proved to be infected, and numerous partial sequences of previously unknown virus and viroid genomes were detected. These results suggest that the viruses and viroids of ornamental plants do represent a remarkably unknown territory that would merit further more detailed study.

Future studies based on this strategy could be applied to populations of asymptomatic plants as well as ones displaying symptoms, in order to consider the prevalence of the pathogen studied. This would 
would also be important for consideration of implementation of siRNA sequencing as a complement to currently used serological and RT-PCR indexing for the presence of known viruses.

\section{Materials and Methods}

\subsection{Origins of samples and design of matrices}

Ornamental plant samples representing the three main sectors in the ornamental plant industry (cut flowers, pot plants and bulbs) were collected during 2012-2014 in France from diverse production facilities, nurseries, experimental trials and the wholesale flower market in Rungis, France. Plants came primarily from France and The Netherlands, but were also imported from Italy, Israel, China, Japan, Sudan and Columbia. Sample were selected based on the presence of potential viral symptoms including mosaic, necrosis, yellowing, discoloration, streak, mottling, and stunting. The 67 samples included 46 plant species, including both monocots and dicots (Suppl Table 1).

\subsection{RNA extraction}

Total RNAs were isolated using the PureLink® Plant RNA Reagent (Ambion ${ }^{\mathrm{TM}}$, Life Technologies) following the specifications of the provider. Each pool of RNA samples was established with equal amounts of total RNAs or small RNAs from 5 different plant species. To facilitate the interpretation of NGS results, the pools were formed by grouping samples from different plant species in order to minimize the risk of pooling samples harboring identical viruses.

\section{3 siRNA sequencing}

Total RNA samples were sent to Fasteris SA (Plan-les-Ouates, Switzerland) for small RNA library construction and deep sequencing. The library preparation was performed using the Illumina TruSeq® Small RNA Sample Prep Kit. A preliminary polyacrylamide gel size selection of 18-30 nucleotides was performed when sample quality was not sufficient. This additional step can improve the efficiency of library preparation.

An "in-lane" PhiX control spike was included in each lane of the flow-cell. Mapping these spiked control reads against the PhiX reference genome showed that the error rate was $0.21 \%$ mismatches. $94.67 \%$ of the reads had a quality value $(\mathrm{Q} 30) \geq 30$, i.e. less than 1 error in 1000 bases. The sequences corresponding to 5' and 3' adaptors were removed according to Fasteris' standard protocols. Except for HBZ-66, most of the inserts found have a length ranging from 18 to 26 bases. 
For HBZ-66, $62.58 \%$ of inserts have a size ranging from 1 to 17 bases.

Sequence data are available at the NCBI Sequence Read Archive (XXX).

\subsection{Bioinformatic analysis}

For each sample, the 21-24 nt reads were imported into the CLC Genomics Workbench version 7 (Qiagen, Hilden, Germany), as shown schematically in Suppl Fig. 1. Each 21-24 nt set of reads was assembled de novo three times, using the default parameters (Bubble size $=50$, Minimum contig length $=100$, Mismatch cost $=2$, Insertion cost $=3$, Deletion $\operatorname{cost}=3$, Length fraction $=0.5$, Similarity fraction $=0.8$ ), except that word length was either 15,17 or 19 . For each sample, the three pools of assembled contigs of minimum length $100 \mathrm{nt}$ were further assembled together de novo, but this time with word length 21 to yield two pools, the assembled scaffolds and the remainder contigs that were not incorporated into the scaffolds. BLASTn at NCBI as implemented in the CLC Workbench was used to identify sequences with the highest identity to each scaffold and remainder. The resulting tables were exported, and a case-insensitive filter used to only retain ones in which the description of the closest related sequence (top hit) included "vir", which retained all viral and viroid sequences, while discarding nearly all the others.

In most cases, the plant bearing the viral or viroid sequence could be identified by inspection of the matrix of pools. To determine which sample was the source of sequences of interest that appeared only in a horizontal or a vertical pool of a matrix, but not both (orphans), The CLC Genomics Workbench was used to map the reads of the five pools perpendicular to the one bearing the orphan, allowing determination of which perpendicular pool bore siRNAs corresponding to the sequence of interest. The same function was used to determine which sample bore the different potyviral scaffolds and remainder contigs. Inspection of the map read output made it easy to distinguish between two types of cases. Read maps in which the reads mapped to isolated singleton sites on the contig were considered to be spurious, whereas cases in which $>50 \%$ of the contig was covered by blocks of overlapping reads were considered to be positive.

Since these analyses were carried out, pipelines specifically dedicated to assemply of siRNAs to identify viral genes have been described (Barrero et al., 2017; Zheng et al. 2017).

Simplot (Lole et al., 1999) was used to visualize possibly recombinant sequences. The putative recombinant sequence and the two corresponding parental sequences were imported into SimPlot. The following parameters were used: Window: 140 pb, Step: 20 pb, GapStrip: On, Kimura (2parameter), $\mathrm{T} /: 2.0$. 


\section{Results}

\subsection{Pilot study}

Ten plants suspected of being virus infected, including nine ornamentals and one crop plant, were selected for a pilot study. The aim was to determine if samples could be pooled without excessive loss of the ability to detect the viruses present, and if the costs could be reduced by eliminating steps in the protocol for siRNA purification and sequencing. These aims were achieved by comparing the results obtained using the standard protocol for siRNA sequencing on the ten individual samples to those obtained with two pools of five samples, each of which was treated according to three simplified protocols designed to reduce costs (Fig 2). Depending on the protocol, simplifications could reduce costs, by $21-36 \%$. The cost calculations taken into account were samples preparation kits, time for preparation and sequencing kit and time for sequencing. Therefore, the reduction of $21 \%$ to $36 \%$ is made only by reducing the number of library preparation. 2.3 to 4.9 million 21-24 nt reads were obtained for the different samples (Suppl Table 2).

As described in Suppl Fig. 1, the CLC Genomics Workbench was used for de novo assembly of contigs using RNAs of 21-24 nt and three different word lengths to generate scaffolds and "remainder" contigs (those that did not enter into scaffold assembly). As expected, compared to the contigs, the resulting scaffolds had higher N50, maximum length, and average length values (Suppl Table 2). Among the 10 samples, the maximum scaffold length ranged from 466 to 5692 nt. Assembled sequences were compared to the NCBI non-redundant nucleotide sequence database to identify the scaffolds and remainders with similarity to sequences in databases whose description includes "vir", such that all virus and viroid sequences would be retrieved. Among the viral sequences thus identified, only two did not meet the criterion for significance, $E<10^{-5}$, and were not considered further.

As shown in Table 3, viral sequences were detected in all ten samples analyzed individually in the pilot study. This included nearly all types of viral genomes, as well as a viroid-like sequence. In some samples, scaffolds longer than $500 \mathrm{nt}$ with $>95 \%$ identity to a known viral genome clearly indicated the presence of a known viral species (highlighted in red). We also consider the presence of Dianthus caryophyllus viroid-like element in carnation HBZ-20 and of Petunia vein clearing virus in petunia HBZ-22 to be certain (highlighted in green), since these pathogens exist as sequences integrated in their host's genome, from which they are transcribed into RNA (Hernandez et al., 1992; Hegedus et al., 2001); thus even if infectious forms of the pathogen were absent, the corresponding siRNAs are expected to be observed. In the cases where scaffolds of $>200 \mathrm{nt}$ with less than $90 \%$ identity to known viral genomes were observed, as in squash HBZ-24 and wild sweetpea HBZ-17, this provided clear evidence for the presence of an as yet unknown virus. This has been confirmed in the case of the Torradovirus in squash HBZ-24, which has been fully characterized, and proposed to constitute a new 
species (Lecoq et al., 2016). Concerning the remaining relatively short viral sequences detected, we propose that they are sufficient to show the presence of a member of the genus in question, but not to determine which species. For instance, in wild sweetpea HBZ-17, several scaffolds and remainders had similar levels of identity to four different luteoviruses, and others to three different ilarviruses, but we consider it likely that only one member of each genus was present. So these situations will be considered to allow identification only to the genus level. In anemone sample HBZ-21, scaffolds and remainders with sequence similarity to five different dsRNA viruses in several genera were observed. Considering that the identities are relatively short $(<500 \mathrm{nt})$, we propose to consider these to show the presence of a dsRNA viral genome.

The analyses of samples HBZ-15 to -24 carried out individually were used as the comparators to determine if we could pool samples in groups of five, and also simplify the siRNA preparation and sequencing strategy. Fig 2 shows the usual and simplified pooling and sequencing strategies. In the reference strategy 1, each sample was treated separately; in strategy 2, total RNAs from 5 samples were pooled before isolation of siRNAs; in strategy 3 , siRNAs were pooled after being purified on acrylamide gels; in strategy 4, total RNAs from 5 samples were pooled, siRNAs were not purified before adaptor ligation and cDNA synthesis. The pools were constructed as shown in Table 4; samples HBZ-15 to -19 were pooled, as were HBZ-20 to -24, and each pool analyzed with the three simplified strategies, after which viral sequences were assembled and extracted as previously (Suppl Fig 1).

The third column of Table 4 shows all the viruses that would be predicted to be present in the pools, i.e. all the viruses detected when the samples were analyzed separately (Table 3), and the fourth column of Table 4 presents the expected viruses that were not observed in the pooled analyses. In all pools, whatever sequencing strategy was used, certain viruses were not detected, which can be explained by the greater dilution of the siRNAs representing each virus in the pools relative to the analyses of individual sample. In pools HBZ-11, -13 and -25 , the missing viruses were two of four viruses that were detected as short sequences ( $<500 \mathrm{nt}$ ) identified to genus level, and in pools HBZ-12, -14 , and -26 , the missing viruses were either an integrated virus or a dsRNA viruses. Thus, all the viruses that yielded contigs $\geq 400 \mathrm{nt}$ were easily detected in the pools. Furthermore, since there were no differences between the viruses detected using the three simplified protocols, any of them could be used in the full-scale experiment presented below.

\subsection{Full-scale study}

The pilot study showed that pooling five samples and using a simplified protocol did not lead to unacceptable loss of ability to detect viral genomes. However, the disadvantage of pooling is that 
identification of the pool member positive for a virus would require further analyses, e.g. by virusspecific RT-PCR of each sample constituting the pool. The aim of the full-scale study was to evaluate whether direct identification of the virus-positive pool members could be achieved by organizing pools of five samples in a matrix, as shown in Suppl Fig 3. For instance, if the same virus is detected in horizontal pool B and vertical pool $\mathrm{H}$, it is present in sample 8, at the intersection of the pools. To test this, a total of 75 samples was organized in three $5 \times 5$ matrices, of which 55 ornamental plant samples, the others being related to other sequencing projects that will not be presented here. Since Matrix 3 was entirely composed of ornamental plants, it will be presented in detail. Each pool of Matrix 3 was composed of five plants of distantly related species, since closely related plants are more likely to be infected by the same virus species, which would make it difficult to determine which sample contributed a particular viral sequence. Sequencing libraries were prepared from the 30 pools corresponding to the three $5 \times 5$ matrices according to strategy 4, the simplest one (Fig. 2), but for 3 pools, this yielded no PCR-amplified product, probably due to the presence of inhibitory substances in one or more samples. So the potentially problematic samples were replaced, and strategy 2 was used for all samples, which yielded satisfactory result.

In Matrix 3, the yield of 21-24 nt reads was more variable than in the pilot study, ranging from $7.5 \mathrm{M}$ in HBZ-65 to 1.8 M in HBZ-66 (Suppl Table 5), for which we have no precise explanation.

Consequently the number of viral scaffolds and remainder contigs was also highly variable, but viral sequences were assembled from the reads of all pools (Table 6). Globally, 50\% of the scaffolds were viral, and the proportion of scaffolds with low similarity to known sequences $\left(E>10^{-5}\right)$ was low, $12.9 \%$. Since the remainder contigs are shorter than the scaffolds, it was expected that the proportion of them with similarity to known sequences below $E>10^{-5}$ was greater, and fewer of them were identified as viral.

As shown in Table 7, viral sequences were detected in all ten pools of Matrix 3, many of which had $>90 \%$ identity to known viruses and were considered to be identified to species. In all ten pools there were also sequences of lower sequence identity to known pathogens, which were identified to genus. When the pools were presented in matrix format (Fig. 4), the vast majority of virus/viroid species could be attributed to specific individual samples. For instance, Impatiens necrotic spot virus (INSV) was only detected in pools HBZ-52 and -64, and was thus unambiguously localized to anemone V088. Similarly, two sequences identified to genus could be attributed to a precise sample, a Badnavirus to canna V132 and a Partitivirus to anemone V088.

Further efforts were required to determine from which samples the few remaining virus/viroid sequences originated. For instance, the Alstroemeria mosaic virus (AlMV) and Lily symptomless virus (LSV) sequences in pool HBZ-51 and the Ilarvirus in pool HBZ-66 could be considered orphans, since no scaffolds or contigs of these viruses were assembled from the five pools perpendicular to the 
pools in which they were found. However, we were able to unambiguously determine which sample harbored these viruses by mapping the 21-24 nt reads of the five pools perpendicular to the one bearing the orphan sequence. For instance, when the reads of pools HBZ-52 -53, -54, -55, and -66 were mapped individually on the AlMV and LSV scaffolds of pool HBZ-51, reads covering more than $50 \%$ of the scaffolds were only observed in pool HBZ-52, thus localizing the two viruses to alstroemeria V098. Similarly, mapping the reads from perpendicular pools showed that the Ilarvirus sequence in pool HBZ-66 was in daisy V139.

The same strategy of read mapping was used to identify which samples bore the sequences identified as belonging to genus Potyvirus in three horizontal and three vertical pools. This was possible because potyviruses are highly diverse, and thus the potyviral sequences observed in the six pools were likely from different members of the genus. For instance, when the reads of pools HBZ-52 -53, $54,-55$, and -66 were mapped on the potyviral sequences of pool HBZ-65, reads covering more than $50 \%$ of each scaffold were only observed in pools HBZ-52 and -66, thus localizing two potyviruses, one in anemone V089 and a different one in ranunculus V090. In the latter case, the potyvirus sequences could be from the remaining part of the Ranunculus leaf distortion virus (RanLDV) genome, of which there is only a partial sequence in the NCBI database. Similarly, the potyvirus sequences in alstroemeria V098 and ranunculus V095 may correspond to the remaining parts of Alstroemeria mosaic virus (AlMV) and Ranunculus mild mosaic virus (RanMMV), respectively. That the different viruses were correctly attributed to the right sample was confirmed by sequencing RTPCR products amplified from RNAs of 10 individual samples; in all cases, using primer pairs specific to the scaffolds examined led to the amplification of the corresponding viral sequences, with the expected levels of sequence identity to reference viral genomes in the NCBI nucleotide database (Table 8).

It remained to determine which samples were responsible for the presence of the Tomato spotted wilt virus (TSWV) sequences in two horizontal pools (HBZ-47 and -48) and two vertical pools (HBZ-53 and -55). Since intra-specific sequence diversity among the TSWV sequences was low, it was not possible to distinguish which samples contributed the TSWV sequences by read mapping. TSWVspecific primers were used to evaluate the presence of the virus in the four potentially TSWV-positive samples (canna V132, peony V118, primrose V099, ranunculus V095), of which only the latter could be demonstrated to be TSWV positive. In principle, at least one of the three remaining samples should have been positive, but no TSWV-specific amplification was observed, although the possibility of sample contamination cannot be formally excluded (Kreuze et al., 2009).

The presence of orphan scaffolds and remainder contigs (ones appearing in only one pool in the matrix) showed that the depth of sequencing was probably insufficient to detect all viruses present. Since each sample in a matrix was present in one horizontal and one vertical pool, greater sequencing 
depth could be achieved by assembling de novo the 21-24 nt reads of all two-by-two combinations of horizontal and vertical pools. For example the 21-24 nt reads of pools HBZ-47 and -54 were assembled together to generate deeper sequence results for peony V116. For all 25 populations of two-by-two assembled pools, viral/viroid sequences were identified as previously (Suppl Fig 1), and read mapping was used to determine which sample bore the sequences of any new pathogen not previously observed. In Matrix 3, this showed that sequences related to Mulberry viroid-like RNA were present in Peony V116, and several other similar cases were found in the two other matrices that were partially composed of ornamental samples (not shown).

Viewed globally, considering all 67 plant samples representing 46 species of the pilot and full-scale study, all ten plants of the pilot study were infected, as were 32 of the 57 samples of the full-scale study, and all the major types of viral/viroid pathogens were detected (Table 9 and Suppl Table 10). As could be expected, species of single-stranded plus-sense RNA viruses were most numerous, with more than 30 species detected. Of these, members of the genus Potyvirus were particularly numerous. A single quarantine pathogen was detected, Tobacco ringspot virus (TRSV) present in Cleome HBZ15 and V129. Considering that ornamental species have been studied much less than crops, it was not surprising to discover numerous previously undescribed virus/viroid sequences (Table 11). And it is of note that we observed four cases of new plant hosts for known viruses (Table 12). Since there are known cases of single- and double-stranded DNA and viroid sequences integrated in host genomes, it should be noted that the results obtained regarding these classes of pathogens do not allow distinguishing between integrated sequences and infectious viruses.

\subsection{Potentially recombinant scaffolds}

Remarkably, one 444 nt viral scaffold assembled from pool HBZ-25 of the pilot study was clearly chimeric, with different parts having high identity to two completely unrelated viruses. The first 280 nt had 93\% identity to RNA 1 of Tobacco ringspot virus (TRSV), and the remaining $166 \mathrm{nt}$ had 100\% identity to Tomato spotted wilt virus (TSWV) RNA segment S (Suppl Fig. 5). This was clearly due to an assembly artifact, since these two viruses were present in different samples when analyzed separately (HBZ-15 and HBZ-18, respectively, Table 3). Upon inspection, the two viral genomes share $12 \mathrm{nt}$ of perfect identity (GAAGAAGGGGAA) at the site of junction in the scaffold. Examination of the contigs assembled using different word lengths showed that the misassembly only occurred when a length of $15 \mathrm{nt}$ was used, and not at 17 or $19 \mathrm{nt}$. For the purpose of this study, detection of viral genomes, the presence of this type of misassembly is not of great concern, but would be if the objective were obtaining complete, authentic sequences of viral isolates. 
Another intriguing case was presented by two potentially recombinant scaffolds of Ornithogalum mosaic virus (OrMV) in iris V082. The clearest potential recombinant was scaffold 11 of pool HBZ46 , which was composed of alternating blocks of sequence nearly identical to two divergent isolates of OrMV, JN127345 and FJ573184, that share 78\% sequence identity (Suppl Fig. 6). This scaffold could either represent a genuine recombinant isolate of OrMV, or otherwise could be the product of misassembly of siRNAs corresponding to the two parental isolates, present in the same sample. When RT-PCR was carried out on total RNA of iris V082 using primers that spanned two recombination crossovers of scaffold 11, the sequences obtained (positions indicated by V082-24 and -25 in Suppl Fig. 6) were 99\% and 98\% identical to JN127345 and FJ573184 over their full lengths, respectively, and the crossovers of scaffold 11 were not observed. These results strongly suggest that the potential recombinant scaffold 11 was also produced by artefactual mis-assembly of siRNAs derived from coinfecting isolates of OrMV that are closely related to JN127345 and FJ573184. Examination of the contigs assembled using different word lengths showed that the mis-assembly occurred with all three word lengths $(15,17$ or $19 \mathrm{nt})$, and thus was not due to assembly of contigs to generate the scaffold.

\section{Discussion}

This feasibility study showed that the strategy of pooling samples and analyzing them in $5 \times 5$ matrices can be remarkable effective, since in a total of 67 samples representing 46 plant species, sequences representing 25 potentially new virus and viroid species were detected (Table 11). However, this strategy has limitations; for instance, in Matrix 3, the presence of the same virus (TSWV) in several horizontal and vertical pools made it impossible to directly read from the matrix in which samples TSWV was present. Thus, in future studies using this approach, it will be important to avoid situations in which the same viruses are expected in numerous samples composing a matrix. In contrast, it would be particularly attractive to verify the virus-free status of a collection of samples, since the presumption would be that few individuals would be infected.

We describe two clear cases of de novo assembly of artefactual recombinant contigs. Within the goals of the present project, which was primarily to detect viruses, this is not a major problem. However it would be a serious problem if the aim were to determine bona fide complete genome sequences. If that is the primary goal, it would be appropriate to confirm sequences by classic sequencing of PCR or RT-PCR products, or otherwise use a strategy that would be based on longer reads, such as those obtained by sequencing double-stranded RNAs the contents of virus-like particles, or ribo-depleted RNAs.

In future studies, it would be highly desirable to achieve greater sequencing depth than those obtained here. This would relieve the problem of orphan scaffolds and remainder contigs, and could also 
clarify the status of short contigs with relatively weak sequence similarity to virus or viroid sequences. Since the cost of sequencing can be expected to continue to decrease, this should be a realistic costeffective goal. Further simplifications that could entail major cost reductions should be possible. Particularly if automation of sample preparation is an obvious goal, eliminating the necessity to purify small RNAs on acrylamide gels would be important, and protocols for doing so have been reported (e.g. Peng et al., 2014). It would also be pertinent to examine whether more sophisticated pooling strategies (e.g. 3-D matrices of pools or the strategy described by Erlich et al., 2009) would reduce the numbers of uncertain attributions of a virus to a precise sample, a problem encountered with TSWV in the full-scale study. In the longer term, a semi-automated system for detecting plant viruses and viroids by siRNA sequencing would be a highly useful tool for following the populations of these pathogens in the ever-changing world of ornamental plants. And furthermore, the strategy for largescale siRNA sequencing could be of great use for discovering viruses in other types of organisms where siRNA synthesis is an important feature of virus resistance, such as nematodes and insects.

The results presented here justify larger similar studies to evaluate the diversity of viruses and viroids of ornamental plants, particularly ones that are circulating worldwide commercially. However, it is important to consider their implications within a wider framework of epidemiological risk. In this regard, studies on invasive organisms can provide guidance. It has been shown in many studies that the number of successful invasive organisms is related to the volume of commerce, whether invasive plants, insects or plant pathogens are concerned (Paini et al. 2016; Hulme 2009; Westphal et al., 2008). The ongoing increase in commerce in ornamental plants could thus be a reason for real concern in the light of the number of previously undescribed pathogens detected in this study. In terms of the steps in the invasion process (introduction, lag phase, establishment, expansion (Marisco et al., 2010)), our results suggest that the number of virus and viroid species that could be introduced via ornamental plants may be high. But since we selected plants that presented possible symptoms, these results do not represent the prevalence of these pathogens in ornamentals, which would be the equivalent of propagule pressure in terms of invasive species. Furthermore, we know very little about the likelihood of the later steps, such as establishment of viruses once they have been introduced. A critical question may be the degree of access of the main vectors of plant viruses (aphids, whiteflies, thrips, nematodes), to the imported ornamentals. This would be expected to be much lower for imported cut flowers, compared to the longer-lasting pot plants, bulbs and tubers. And these different types of ornamentals also pass through commercial circuits of different lengths: very short for cut flowers, longer for bulbs and tubers, and even longer for plants multiplied locally after import. The length and complexity of these circuits would have an effect on the likelihood of interactions with vectors. The relative rarity of invasive plant viruses being associated with importing ornamental plants may suggest that the actual epidemiological risk would be lower than what appears from the richness of initial introductions we have observed. However, it is important to consider that there is 
often a lag phase of varying length between introduction and establishment of invasive organisms, in which case some of the novel pathogens we have observed could become established at some later date. Evaluating the risks associated with viruses harbored by ornamental plants represents an ambitious goal, which would require not only better understanding of their introduction, as could be done by further studies like this one, as well as an estimation of virus/viroid prevalence, but also better understanding of the parameters that would allow evaluation of the potential for establishment and the overall epidemiological risk.

\section{Acknowledgements}

We thank Fabien Robert of ASTREDHOR (Association nationale des structures d'expérimentation et de démonstration en horticulture) for allowing us to contact many of the advisors and producers of the ornamental sector who provided samples for this project, and Marie-Laure Winocq, AREXHOR (Association régionale d'expérimentation horticole) who provided particularly numerous ornamental samples. We thank Gregory Girardot, Jonathan Gaudin, and Antoine Lauvernay for assistance with sample preparation. We thank Florian Maumus for excellent suggestion on the manuscript.

The IJPB has benefitted from a French State grant (LabEx Saclay Plant Sciences-SPS, ref. ANR-10LABX-0040-SPS), managed by the French National Research Agency under an "Investments for the Future" program (ref. ANR-11-IDEX-0003-02). This specific research project was supported by the INRA Plant Health and Environment Department Bioresources Program contract P03006.

\section{References}

Anonymous, 2006a. Isolated finding of Potato spindle tuber viroid on Solanum jasminoides in the Netherlands. EPPO Reporting Service 07-2006, 2006-142.

Anonymous, 2006b. Isolated finding of Potato spindle tuber viroid on Solanum jasminoides in Germany. EPPO Reporting Service 08-2006, 2006-159.

Anonymous, 2006c. Further finding of Potato spindle tuber viroid on ornamental Solanaceae in the Netherlands. EPPO Reporting Service 11-2006, 2006-229.

Barrero, R.A., Napier, K.R., Cunnington, J., Liefting, L. Keenan, S., Frampton, R.A., Szabo, T., Bulman, S., Hunter, A., Ward, L., Whattam, M., Bellgard, M.I. 2017. An internet-based bioinformatics toolkit for plant biosecurity diagnosis and surveillance of viruses and viroids. $B M C$ Bioinformatics. 18, doi 10.1186/s12859-016-1428-4. 
Di Serio, F., 2007. Identification and characterization of Potato spindle tuber viroid infecting Solanum jasminoides and S. rantonnetii in Italy. J. Plant Pathol. 89, 297-300.

Erlich, Y., Chang, K., Gordon, A., Ronen, R., Navon, O., Rooks, M., Hannon, G.J., 2009. DNA Sudoku - harnessing high-throughput sequencing for multiplexed speciment analysis. Genome Res. $19,1243-1253$.

Hegedus, K., Palkovics, L., Toth, E.K., Dallmann, G., Balazs, E., 2001. The DNA form of a retroviroid-like element characterized in cultivated carnation species. J. Gen. Virol. 82, 687-691.

Hernandez, C., Daros, J.A., Elena, S.F., Moya, A., Flores, R., 1992. The strands of both polarities of a small circular RNA from carnation self-cleave in vitro through alternative double- and singlehammerhead structures. Nucleic Acids Res. 20, 6323-6329.

Hulme, P.E., 2009. Trade, transport and trouble: managing invasive species pathways in an era of globalization. J. Appl. Ecol. 46, 10-18.

Kreuze, J.F., Pérez, A., Untiveros, M., Quispe, D., Fuentes, S., Barker, I., Simon, R. 2009. Complete viral genome sequence and discovery of novel viruses by deep sequencing of small RNAs: a generic method for diagnosis, discovery and sequencing of viruses. Virology 388: 1-7 DOI 10.1016/j.virol.2009.03.024

Lecoq, H., Verdin, E., Tepfer, M., Wipf-Scheibel, C., Millot, P., Dafalla, G., Desbiez, C., 2016. Characterization and occurrence of squash chlorotic leaf spot virus, a tentative new torradovirus infecting cucurbits in Sudan. Arch. Virol. 161, 1651-1655.

Li, R., Gao, S., Hernandez, A.G., Wechter, W.P., Fei, Z, Ling, K.S. 2012. Deep Sequencing of Small RNAs in Tomato for Virus and Viroid Identification and Strain Differentiation. PLoS ONE 7: e37127.

Lole, K.S., Bollinger, R.C., Paranjape, R.S., Gadkari, D., Kulkarni, S.S., Novak, N.G., Ingersoll, R., Sheppard, H.W., Ray S.C., 1999. Full-Length Human Immunodeficiency Virus Type 1 Genomes from Subtype C-Infected Seroconverters in India, with Evidence of Intersubtype Recombination. J. Virol. $73,152-160$.

Marisco, T.D., Burt, J.W., Espeland, E.K., Gilchrist, G.W., Jamieson, M.A., Lindstrom, L., Roderick, G.K., Swope, S., Szucs, M., Tsutsui, N.D., 2010. Underutilized resources for studying the evolution of invasive species during their introduction, establishment and lag phases. Evol. Appl. 3, 203-219.

Martin, R. R., Constable, F., Tzanetakis, I.E. Quarantine Regulations and the Impact of Modern Detection Methods. Ann. rev. phytopathol. 54, 189-205.

Paini; D.R., Sheppard, A.W., Cook, D.C., De Barro, P.J., Worner, S.P., Thomas, M.B., 2016. Global threat to agriculture from invasive species. Proc. Natl. Acad. Sci. USA. 1134, 7575-7579. 
Peng, J., Xia, Z., Chen, L., Shi, M., Pu, J., Guo, J., Fan Z., 2014. Rapid and Efficient Isolation of High-Quality Small RNAs from Recalcitrant Plant Species Rich in Polyphenols and Polysaccharides. PLoS ONE e95687.

Roossinck, M. J., Martin, D. P., Roumagnac, P., 2015. Plant virus metagenomics: Advances in virus discovery. Phytopathol. 105, 716-727.

Westphal, M.I., Browne, M., MacKinnon, K., Noble, I., 2008. The link between international trade and the global distribution of invasive alien species. Biol. Invasions 10, 391-398.

Wu, Q., Ding, S.-W., Zhang, Y., Zhu, S. Identification of viruses and viroids by next-generation sequencing and homology-dependent and homology-independent algorithms. Ann. rev. phytopathol. 53, 425-444.

Zheng, Y., Gao, S., Padmanabhan, C., Li, R., Galvez, M., Gutierrez, D., Fuentes, S., Ling, K.-S., Fei, Z. 2017. VirusDetect: An automated pipeline for efficient virus discovery using deep sequencing of small RNAs. Virology 500,130-138.

\section{Figure legends}


Import 21-24 nt reads

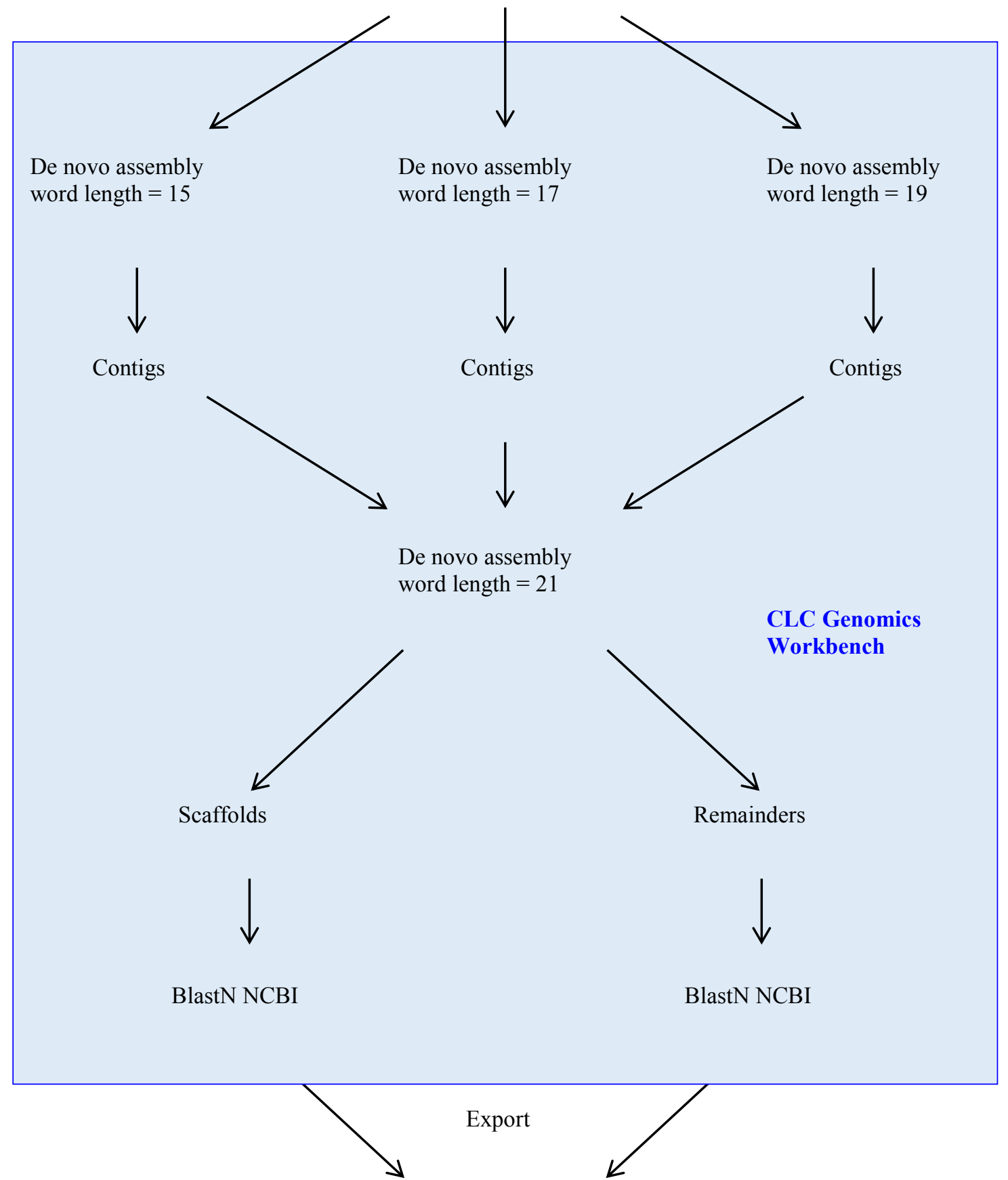

Excel tables of scaffolds and remainders<smiles>[AlH2]</smiles>

Filter for "vir" (Excel)<smiles>C=[V]</smiles>

Compilation of viruses present in sample

Fig. 1 (suppl) Bioinformatics strategy 
Fig. 2. Pooling and sequencing strategies

Usual protocol for sequencing small RNAs:

1. Purification of total RNA samples

2. Isolation of small RNAs on acrylamide gel

3. Ligation of 3' adaptors

4. Ligation of 5' adaptors

5. cDNA synthesis

6. PCR

7. Purification of PCR products on acrylamide gel

8. Sequencing

\begin{tabular}{ll}
\hline Strategy & $\begin{array}{l}\text { Percent cost } \\
\text { reduction }\end{array}$ \\
\hline $\begin{array}{l}\text { Strategy 1 } \\
\text { Usual protocol, each sample treated individually }\end{array}$ & \\
Strategy 2 \\
$\begin{array}{l}\text { Total RNA samples pooled before isolation of small RNAs } \\
\text { (after Step 1) }\end{array}$ \\
$\begin{array}{l}\text { Strategy 3 } \\
\text { Small RNAs pooled after isolation on polyacrylamide gel } \\
\text { (after step 2) }\end{array}$ \\
$\begin{array}{l}\text { Strategy 4 } \\
\text { Ligation of 3, adaptors on pooled total RNA samples } \\
\text { (after step 1, step 2 omitted) }\end{array}$ \\
\hline
\end{tabular}




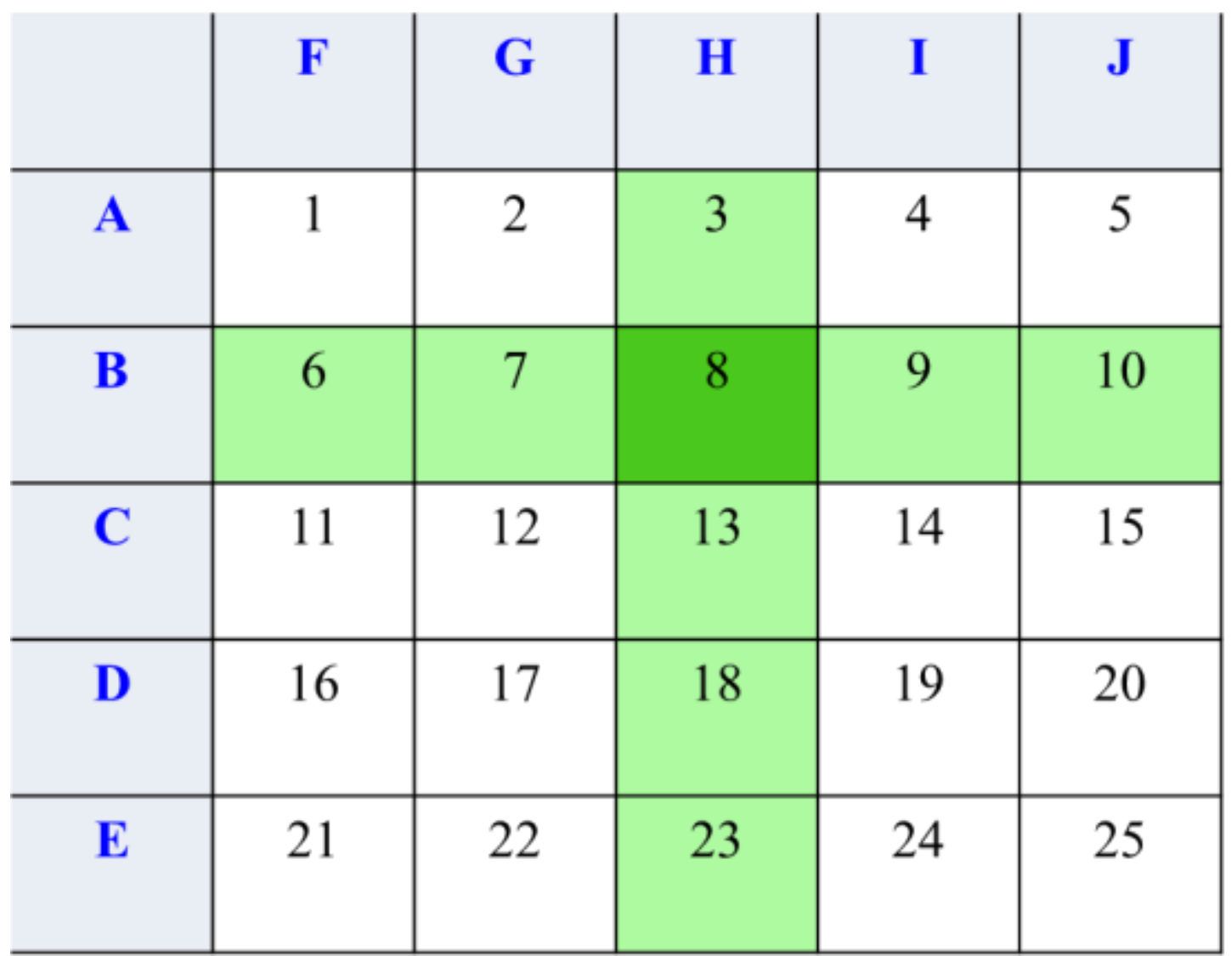

Fig. 3 (suppl) Full-scale study: Example of a matrix of 10 pools (A to J) of 25 samples. If the green virus is present in pools $\mathrm{B}$ and $\mathrm{H}$, it is in fact from sample 8 .

Cost-effectiveness: 10 pools sequenced, rather than 25 samples 


\begin{tabular}{|c|c|c|c|c|c|c|}
\hline & & $\begin{array}{l}\text { Impatiens necrotic spot virus } \\
\text { Ranunculus leaf distortion virus } \\
\text { Partitivirus } \\
\text { Potyvirus }\end{array}$ & $\begin{array}{l}\text { Petunia vein clearing virus } \\
\text { Ranunculus mild mosaic virus } \\
\text { Tomato spotted wilt virus } \\
\text { Potyvirus }\end{array}$ & $\begin{array}{l}\text { Tobacco rattle virus } \\
\text { Tobacco ringspot virus } \\
\text { Cycas necrotic stunt virus }\end{array}$ & $\begin{array}{l}\text { Canna yellow streak virus } \\
\text { Cycas necrotic stunt virus } \\
\text { Tomato spotted wilt virus } \\
\text { Bean yellow mosaic virus } \\
\text { Potyvirus } \\
\text { Badnavirus }\end{array}$ & Ilarvirus \\
\hline & & HBZ-52 & HBZ-53 & HBZ-54 & HBZ-55 & HBZ-66 \\
\hline $\begin{array}{l}\text { Bean yellow mosaic virus } \\
\text { Canna yellow streak virus } \\
\text { Ranunculus mild mosaic virus } \\
\text { Tobacco rattle virus } \\
\text { Tomato spotted wilt virus } \\
\text { Potyvirus } \\
\text { Badnavirus }\end{array}$ & HBZ-47 & V085 (guzmania) & $\begin{array}{l}\text { V095 (ranunculus) } \\
\text { Tomato spotted wilt virus } \\
\text { Ranunculus mild mosaic virus } \\
\text { Potyvirus (may be rest of } \\
\text { RMMV) }\end{array}$ & $\begin{array}{l}\text { V116 (peony) } \\
\text { Tobacco rattle virus } \\
\text { Mulberry viroid-like RNA } \\
\text { (V116 scaffold18) }\end{array}$ & $\begin{array}{l}\text { V132 (canna) } \\
\text { Tomato spotted wilt virus? } \\
\text { Canna yellow streak virus } \\
\text { Bean yellow mosaic virus } \\
\text { Badnavirus } \\
\text { Potyvirus }\end{array}$ & $\begin{array}{l}\text { V139 (daisy) } \\
\text { Ilarvirus }\end{array}$ \\
\hline $\begin{array}{l}\text { Tomato spotted wilt virus } \\
\text { Cycas necrotic stunt virus }\end{array}$ & HBZ-48 & V086 (dracaena) & $\begin{array}{l}\text { V099 (primrose) } \\
\text { Tomato spotted wilt virus? }\end{array}$ & $\begin{array}{l}\text { V120 (snapdragon) } \\
\text { Cycas necrotic stunt virus }\end{array}$ & $\begin{array}{l}\text { V118 (peony) } \\
\text { Tomato spotted wilt virus? } \\
\text { Cycas necrotic stunt virus }\end{array}$ & V141 (holly) \\
\hline $\begin{array}{l}\text { Impatiens necrotic spot } \\
\text { Partitivirus }\end{array}$ & HBZ-64 & $\begin{array}{l}\text { V088 (anemone) } \\
\text { Impatiens necrotic spot virus } \\
\text { Partitivirus }\end{array}$ & V100 (geranium) & V122 (lisianthus) & V133 (chrysanthemum) & V001 (petunia) \\
\hline $\begin{array}{l}\text { Ranunculus leaf distortion virus } \\
\text { Petunia vein clearing } \\
\text { Potyvirus }\end{array}$ & HBZ-65 & $\begin{array}{l}\text { V090 (ranunculus) } \\
\text { Ranunculus leaf distortion virus } \\
\text { Potyvirus (may be rest of } \\
\text { RanLDV) }\end{array}$ & $\begin{array}{l}\text { V102 (petunia) } \\
\text { Petunia vein clearing virus }\end{array}$ & V124 (hibiscus) & V134 (tea) & $\begin{array}{l}\text { V089 (anemone) } \\
\text { Potyvirus }\end{array}$ \\
\hline $\begin{array}{l}\text { Alstroemeria mosaic virus } \\
\text { Tobacco ringspot virus } \\
\text { Tobacco rattle virus } \\
\text { Lily symptomless virus } \\
\text { Potyvirus }\end{array}$ & HBZ-51 & $\begin{array}{l}\text { V098 (alstroemeria) } \\
\text { Alstroemeria mosaic virus } \\
\text { Lily symptomless virus } \\
\text { Potyvirus (may be rest of AlMV) }\end{array}$ & V106 (dicentra) & $\begin{array}{l}\text { V129 (cleome) } \\
\text { Tobacco ringspot virus } \\
\text { Tobacco rattle virus }\end{array}$ & V137 (pansy) & V145 (wild tulip) \\
\hline
\end{tabular}

Fig. 4 Full-scale study: Viruses present in plants in Matrix 3.

Pool names are indicated on a mid-grey background. The identity of viral sequences observed in each pool is shown above or to the left of pool names on a light grey background.

In black: viral sequences with $>100$ nt having $>90 \%$ identity to a known virus species, localized to a sample by crossing pools.

In brown: viral sequences with $>100 \mathrm{nt}$ having $>90 \%$ identity to a known virus species, localized to a sample by mapping reads to scaffolds and remainder contigs.

In red: viral sequences with $<90 \%$ identity to known virus, identified to genus, localized to a sample by crossing pools.

In blue: viral sequences with $<90 \%$ identity to known virus, identified to genus, localized to sample by mapping reads to scaffolds and remainder contigs.

In green: viral or viroid sequence observed in de novo assembly of sums of reads in pairs of crossed pools, localized to sample by mapping reads.

?: Virus may be present, but not confirmed by RT-PCR. 


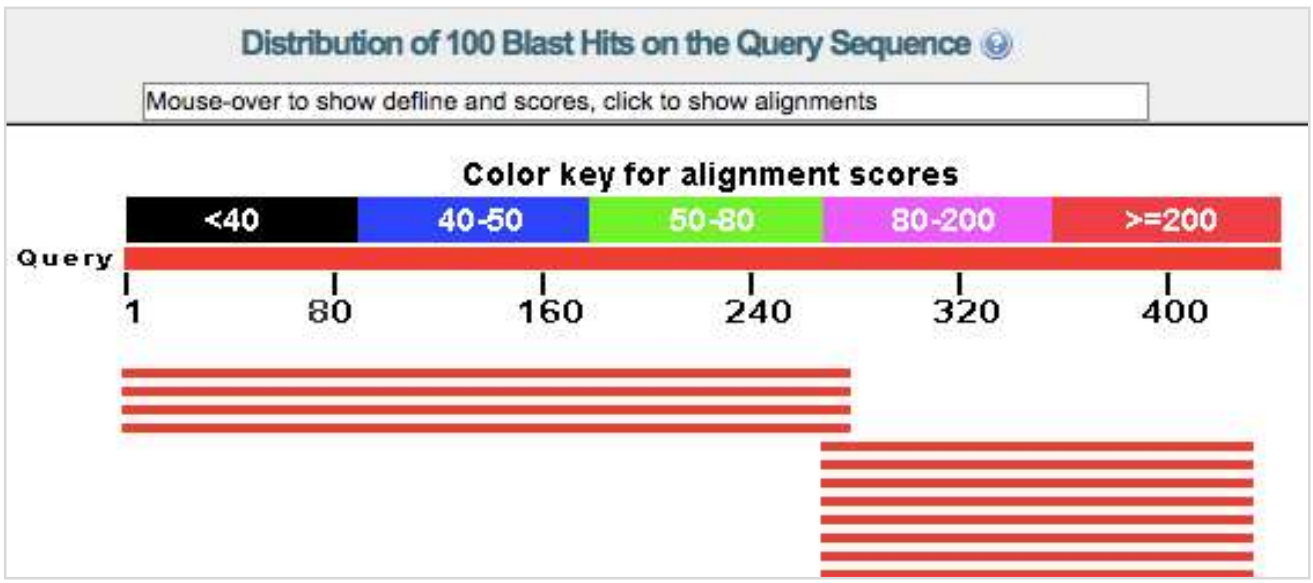

B

Tobacco ringspot virus partial RdRp gene for polyprotein, genomic RNA

Sequence ID: emb|AJ698718.1|Length: 761Number of Matches: 1

Related Information

Range 1: 242 to 521 GenBankGraphics Next Match Previous Match

Alignment statistics for match \#1

\section{Score Expect Identities Gaps Strand}

410 bits(454) 9e-111 259/280(93\%) 0/280(0\%) Plus/Plus

\begin{tabular}{|c|c|c|}
\hline Query & 1 & TGGAATTGCCCAAAAATATGCTTTTTAGGAAGAAATTTTTGCATTGGGCTTTATTTCTCT \\
\hline Sbjet & 242 & 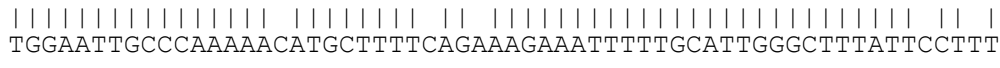 \\
\hline Query & 61 & 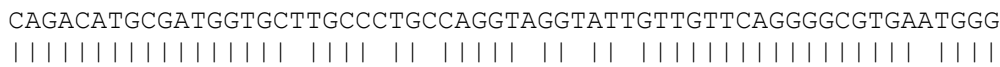 \\
\hline Sbjet & 302 & CAGACATGCGATGGTGCCTGCCGTGTCAGGTGGGCATCGTTGTTCAGGGGCGTGAGTGGG \\
\hline Query & 121 & $\begin{array}{l}\text { GGCTCCTGATGGACCGTCTTGCTGCGAAGAACTCGGTTGCATATAACTGTGATTATTCAA } \\
|||||||||||||||||||||||||||||||||||||||||||||||||||||||||||||| \text { | }\end{array}$ \\
\hline Sbjet & 362 & GGCTCCTGATGGATCGTCTTGCTGCGAAGAATTCGGTTGCTTACAACTGTGATTATTCTA \\
\hline Query & 181 & $\begin{array}{l}\text { AGTTTGATGGCCTCATGTCTTGTCAGGTGTTGGATGCTATAGGAAAAATGGTAAATAAAT } \\
|||||||||||||||||||||||||||||||||||||||||||||||||||||||||||||||| \mid)\end{array}$ \\
\hline Sbjet & 422 & AGTTTGATGGTCTCATGTCTTGTCAGGTGTTGGATGCTATAGGTAAAATGGTGAATAAAT \\
\hline Query & 241 & $\begin{array}{l}\text { GCTATTCCAACGCCAACCCCAATTTAAAGAAGAAGGGGAA } 280 \\
|||||||||||||||||||||||||||||||||||||||||||| \mid\end{array}$ \\
\hline sbjct & 482 & GCTATTCCAACGCCAACCCCAATCTAAAGAAGAAGGGGAA \\
\hline
\end{tabular}

Tomato spotted wilt virus isolate p105-RB-MaxII segment S, complete sequence

Sequence ID: gb|HQ839731.1|Length: 2927Number of Matches: 1

Related Information

Range 1: 1985 to 2150GenBankGraphics Next Match Previous Match

Alignment statistics for match \#1

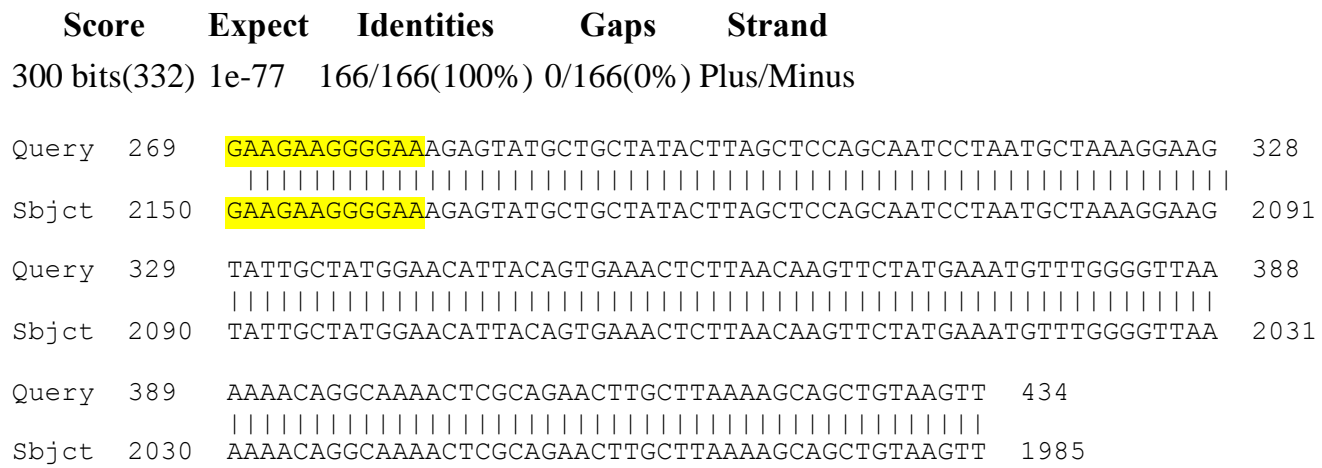

Fig, 5 (suppl) Pilot project: HBZ-25 scaffold 61 is a recombinant due to de novo mis-assembly, shown by BlastN analysis.

A. HBZ-25 scaffold 61 (444 nt) is a chimera composed of TRSV (first $280 \mathrm{nt}$ ) and TSWV (the rest). B. When the sequences are aligned, there is an overlap of $12 \mathrm{nt}$ shared identity that exists in the reference sequences (highlighted in yellow). 


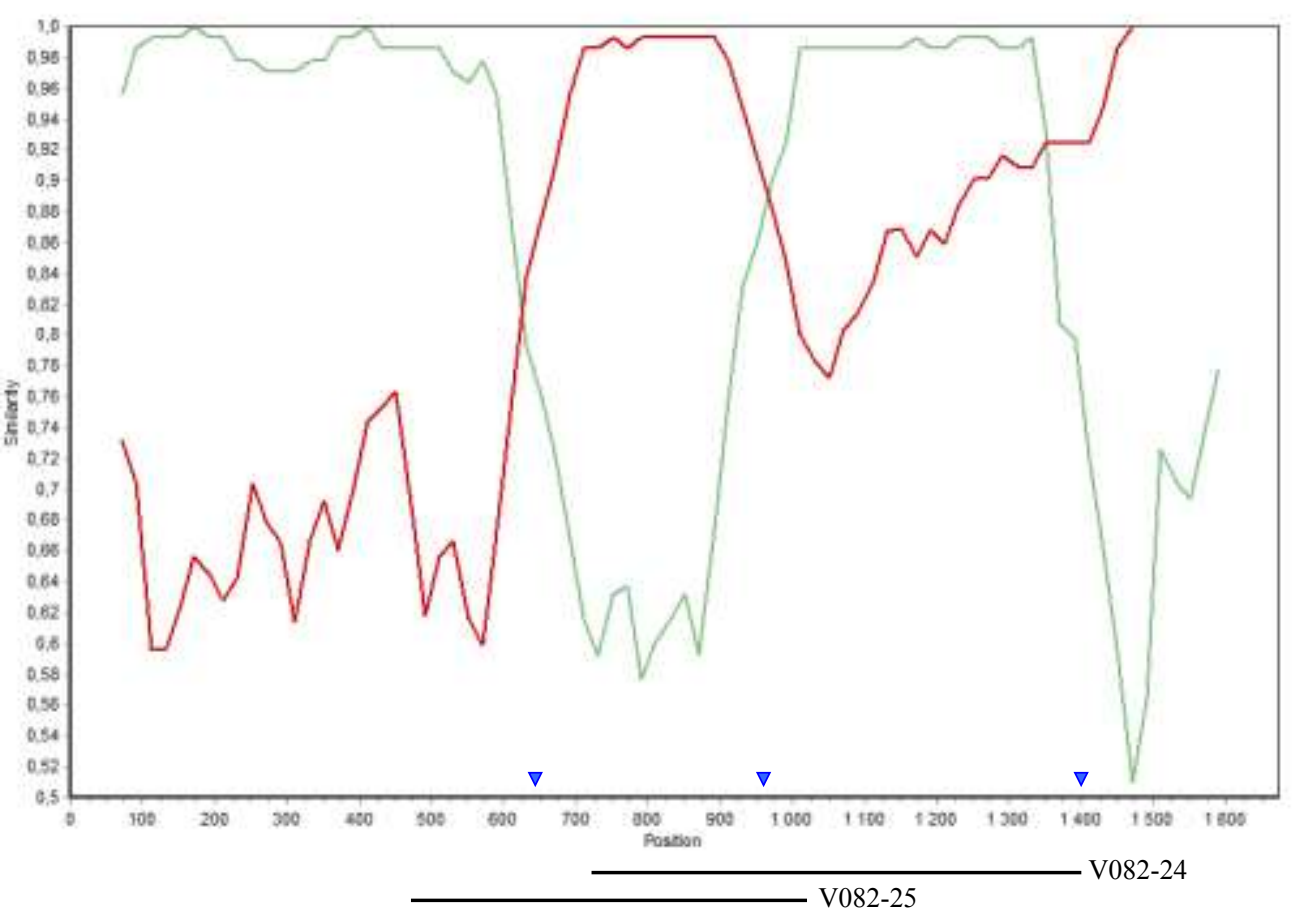

$-71573184$

Fig. 6 Full-scale study: SimPlot analysis of HBZ-46 scaffold 11 (nt 469-2135) of Iris V082.

In BlastN analyses, scaffold 11 appeared to be composed of alternating blocks with high similarity to two divergent isolates of OrMV (accessions FJ573184 and JN127345). This was confirmed in the SimPlot (Lole et al., 1999) analysis presented here, in which red and green lines show similarity to FJ573184 and JN127345, respectively. The position of putative crossovers determined from sequence alignments are shown by blue triangles at the bottom of the graph. The position of sequenced RT-PCR amplification products, V082-24 and -25, are shown below the graph. 
Table 1 (suppl) Identity and source of plant samples

\begin{tabular}{|c|c|c|c|c|c|}
\hline $\begin{array}{l}\text { Sample } \\
\text { number }\end{array}$ & Common name & Latin name & Cultivar & Source & Origin \\
\hline V001 & Petunia & Petunia $\mathrm{x}$ 'Surfinia' & Sanguna Rose Vein & Normandy, France & unspecified \\
\hline V003 & Cleome & Cleome spinosa & Senorita Rosalita & Poitou-Charente, France & unspecified \\
\hline V004 & Verbena & Verbena hybrida & $\begin{array}{l}\text { Donalena Red Pepper } \\
\text { Improved }\end{array}$ & Normandy, France & Israel \\
\hline V005 & Primrose & Primula acaulis & Starflam Purple & Normandy, France & The Netherlands \\
\hline V009 & Geranium & $\begin{array}{l}\text { Pelargonium } \\
\text { zonale }\end{array}$ & Joigny & Ile de France, France & unspecified \\
\hline V012 & Verbena & Verbena hybrida & unspecified & Normandy, France & unspecified \\
\hline V020 & Phlox & Phlox sp. & unspecified & Ile de France, France & unspecified \\
\hline V021 & Cleome & Cleome spinosa & Senorita Rosalita & Aquitaine, France & unspecified \\
\hline V022 & Carnation & Dianthus chinensis & unspecified & Aquitaine, France & France \\
\hline V026 & Geranium & $\begin{array}{l}\text { Pelargonium } \\
\text { zonale }\end{array}$ & unspecified & Normandy, France & France \\
\hline V027 & Geranium & $\begin{array}{l}\text { Pelargonium } \\
\text { zonale }\end{array}$ & Tango Bravo Light Pink & Normandy, France & unspecified \\
\hline V029 & $\begin{array}{l}\text { New Guinea } \\
\text { Impatiens }\end{array}$ & Impatiens hawkeri & unspecified & Normandy, France & France \\
\hline V031 & Verbena & Verbena hybrida & Raspberry & Normandy, France & France \\
\hline V032 & Hydrangea & $\begin{array}{l}\text { Hydrangea } \\
\text { macrophylla }\end{array}$ & Teller & Normandy, France & France \\
\hline V033 & Kalanchoe & Kalanchoe sp & Sephiros & Normandy, France & France \\
\hline V035 & Lilac & Syringa vulgaris & unspecified & Provence, France & France \\
\hline V036 & Wild sweetpea & Lathyrus latifolius & unspecified & Provence, France & France \\
\hline V037 & Periwinkle & $\begin{array}{l}\text { Catharanthus } \\
\text { roseus }\end{array}$ & unspecified & Provence, France & France \\
\hline V039 & $\begin{array}{l}\text { New Guinea } \\
\text { Impatiens }\end{array}$ & Impatiens hawkeri & unspecified & Aquitaine, France & unspecified \\
\hline V046 & Dahlia & Dahlia pinnata & unspecified & Rhônes-Alpes, France & France \\
\hline V047 & Centranthus & Centranthus ruber & unspecified & $\begin{array}{l}\text { Languedoc-Roussillon, } \\
\text { France }\end{array}$ & France \\
\hline V048 & Oleander & Nerium oleander & unspecified & $\begin{array}{l}\text { Languedoc-Roussillon, } \\
\text { France }\end{array}$ & France \\
\hline V051 & Chrysanthemum & $\begin{array}{l}\text { Chrysanthemum } \\
\text { hortorum }\end{array}$ & Lovisette & Normandy, France & France \\
\hline V054 & Cineraria & Cineraria $\mathrm{sp.}$ & unspecified & Normandy, France & France \\
\hline V055 & Velvet leaf & Abutilon sp. & Canary Bird & Aquitaine, France & unspecified \\
\hline V057 & Banana & Musa sp. & unspecified & $\begin{array}{l}\text { Ile de La Réunion, } \\
\text { France }\end{array}$ & $\begin{array}{l}\text { France (La } \\
\text { Réunion) }\end{array}$ \\
\hline V062 & Pomelo & Citrus sp. & unspecified & $\begin{array}{l}\text { Ile de La Réunion, } \\
\text { France }\end{array}$ & $\begin{array}{l}\text { France (La } \\
\text { Réunion) }\end{array}$ \\
\hline V063 & Cyclamen & Cyclamen sp. & unspecified & Normandy, France & France \\
\hline V068 & Alstroemeria & Alstroemeria sp. & unspecified & Rungis, France $^{1}$ & The Netherlands \\
\hline V069 & Hydrangea & Hydrangea sp. & unspecified & Rungis, France & The Netherlands \\
\hline V072 & Lily & Lilium sp. & unspecified & Rungis, France & The Netherlands \\
\hline V074 & Asclepias & Asclepias sp. & unspecified & Rungis, France & Kenya \\
\hline V077 & Carnation & $\begin{array}{l}\text { Dianthus } \\
\text { caryophyllus }\end{array}$ & unspecified & Rungis, France & Colombia \\
\hline V082 & Iris & Iris sp. & unspecified & Rungis, France & France \\
\hline V084 & Green bell & Thlaspi sp. & unspecified & Rungis, France & Israel \\
\hline V085 & Guzmania & Guzmania sp. & unspecified & Rungis, France & unspecified \\
\hline V086 & Dracaeana & Dracaena sp. & unspecified & Rungis, France & unspecified \\
\hline V087 & Snapdragon & Antirrhinum majus & unspecified & Provence, France & France \\
\hline V088 & Anemone & Anemone & Carmel & Provence, France & Israel \\
\hline
\end{tabular}




\begin{tabular}{|c|c|c|c|c|c|}
\hline & & coronaria & & & \\
\hline V089 & Anemone & $\begin{array}{l}\text { Anemone } \\
\text { coronaria }\end{array}$ & Galilee & Provence, France & Israel \\
\hline V090 & Buttercup & $\begin{array}{l}\text { Ranunculus } \\
\text { asiaticus }\end{array}$ & Elegance Rose & Provence, France & Italy \\
\hline V095 & Buttercup & $\begin{array}{l}\text { Ranunculus } \\
\text { asiaticus }\end{array}$ & Pauline Brique & Provence, France & France \\
\hline V098 & Alstroemeria & Alstroemeria sp. & Alexandra & Pays de la Loire, France & unspecified \\
\hline V099 & Primrose & Primula acaulis & unspecified & Pays de la Loire, France & unspecified \\
\hline V100 & Geranium & $\begin{array}{l}\text { Pelargonium } \\
\text { zonale }\end{array}$ & Vulkan 2009 & Normandy, France & unspecified \\
\hline V101 & Anemone & $\begin{array}{l}\text { Anemone } \\
\text { coronaria }\end{array}$ & Jerusalem Rose Fuschia & Provence, France & Israel \\
\hline V102 & Petunia & Petunia x Surfinia & Purpe Stuti Brillant & Normandy, France & unspecified \\
\hline V104 & Petunia & Petunia hybrida & Fanfare Red & Pays de la Loire, France & The Netherlands \\
\hline V106 & Dicentra & $\begin{array}{l}\text { Dicentra } \\
\text { spectabilis }\end{array}$ & unspecified & Pays de la Loire, France & unspecified \\
\hline V114 & Lisianthus & $\begin{array}{l}\text { Eustoma } \\
\text { grandiflorum }\end{array}$ & Mariachi & Provence, France & The Netherlands \\
\hline V116 & Peony & Paeonia lactiflora & Red Charm & Provence, France & The Netherlands \\
\hline V118 & Peony & Paeonia lactiflora & Coral Sunset & Provence, France & France \\
\hline V119 & Lisianthus & $\begin{array}{l}\begin{array}{l}\text { Eustoma } \\
\text { grandiflorum }\end{array} \\
\end{array}$ & Bonealis & Provence, France & The Netherlands \\
\hline V120 & Snapdragon & Antirrhinum majus & unspecified & Provence, France & France \\
\hline V122 & Lisianthus & $\begin{array}{l}\text { Eustoma } \\
\text { grandiflorum }\end{array}$ & Echo & Provence, France & The Netherlands \\
\hline V124 & Hibiscus & Hibiscus sp. & unspecified & Rhônes-Alpes, France & unspecified \\
\hline V129 & Cleome & Cleome spinosa & Senorita rosalita & Poitou-Charente, France & unspecified \\
\hline V132 & Canna & Canna indica & unspecified & $\begin{array}{l}\text { Champagne-Ardenne, } \\
\text { France }\end{array}$ & unspecified \\
\hline V133 & Chrysanthemum & $\begin{array}{l}\text { Chrysanthemum } \\
\text { hortorum }\end{array}$ & unspecified & Pays de la Loire, France & unspecified \\
\hline V134 & Tea & Camelia sinensis & unspecified & Ile de France, France & unspecified \\
\hline V137 & Pansy & Viola sp. & Pensee Matrix Cassis & Normandy, France & unspecified \\
\hline V139 & Daisy & Bellis perennis & unspecified & Normandy, France & unspecified \\
\hline V141 & Holly & Ilex crenata & Kinme & Rhônes-Alpes, France & Japan \\
\hline V142 & Squash & $\begin{array}{l}\text { Cucurbita } \\
\text { moschata }\end{array}$ & unspecified & Sudan & Sudan \\
\hline V145 & Wild tulip & Tulipa raddii & unspecified & Rhônes-Alpes, France & France \\
\hline V146 & Violet & Viola odorata & unspecified & Provence, France & France \\
\hline
\end{tabular}

${ }^{1}$ The National Wholesale Market outside of Paris 
Table 2 (suppl) Pilot study: quality of de novo assembly of contigs and scaffolds

\begin{tabular}{|c|c|c|c|c|c|c|c|c|c|}
\hline \multirow[b]{2}{*}{ Sample } & \multirow{2}{*}{$\begin{array}{c}21-24 \\
\text { nt } \\
\text { reads } \\
\left(10^{6}\right)\end{array}$} & \multicolumn{4}{|c|}{ Contigs $^{l}$} & \multicolumn{4}{|c|}{ Scaffolds $^{I}$} \\
\hline & & N50 & $\begin{array}{l}\text { Maximum } \\
\text { length }\end{array}$ & $\begin{array}{l}\text { Average } \\
\text { length }\end{array}$ & $\begin{array}{l}\text { Total } \\
\text { length }\end{array}$ & N50 & $\begin{array}{l}\text { Maximum } \\
\text { length }\end{array}$ & $\begin{array}{l}\text { Average } \\
\text { length }\end{array}$ & $\begin{array}{l}\text { Total } \\
\text { length }\end{array}$ \\
\hline HBZ-11 & 2.02 & 178 & 960 & 180 & 33458 & 262 & 1029 & 245 & 22080 \\
\hline HBZ-12 & 3.88 & 228 & 1038 & 209 & 32370 & 532 & 1670 & 351 & 23512 \\
\hline HBZ-13 & 3.48 & 173 & 2025 & 184 & 49361 & 257 & 2241 & 259 & 33687 \\
\hline HBZ-14 & 3.73 & 242 & 1372 & 212 & 31127 & 549 & 1372 & 369 & 23246 \\
\hline HBZ-15 & 4.90 & 231 & 3243 & 213 & 36868 & 512 & 5692 & 371 & 33003 \\
\hline HBZ-16 & 2.65 & 216 & 934 & 207 & 13043 & 336 & 1965 & 321 & 9618 \\
\hline HBZ-17 & 3.16 & 191 & 834 & 186 & 47396 & 309 & 1857 & 270 & 31345 \\
\hline HBZ-18 & 3.37 & 190 & 507 & 187 & 17931 & 225 & 583 & 223 & 14701 \\
\hline HBZ-19 & 3.68 & 144 & 952 & 157 & 51888 & 261 & 1515 & 250 & 28710 \\
\hline HBZ-20 & 4.47 & 148 & 1112 & 160 & 27116 & 245 & 1981 & 251 & 14282 \\
\hline HBZ-21 & 2.34 & 143 & 278 & 145 & 6522 & 201 & 506 & 192 & 6928 \\
\hline HBZ-22 & 2.56 & 149 & 466 & 153 & 19183 & 207 & 466 & 203 & 9115 \\
\hline HBZ-23 & 3.20 & 247 & 1343 & 205 & 23587 & 308 & 2149 & 278 & 18095 \\
\hline HBZ-24 & 4.41 & 815 & 1724 & 244 & 27288 & 3415 & 5690 & 625 & 21245 \\
\hline HBZ-25 & 3.21 & 185 & 1676 & 188 & 61306 & 315 & 2861 & 268 & 42669 \\
\hline HBZ-26 & 2.23 & 235 & 807 & 200 & 20013 & 391 & 1291 & 319 & 20760 \\
\hline
\end{tabular}

All samples were analyzed with three word lengths: 15,17 , or 19 . The values shown in the Contigs columns were those obtained with the word length yielding the highest $N 50$ value. The scaffolds were obtained by assembling de novo the contigs obtained with the three word lengths, using word length 21.

${ }^{1}$ All lengths in nucleotides 
Table 3 Pilot study: Analysis of viral scaffolds and remainder contigs of individual plant samples

\begin{tabular}{|c|c|c|c|}
\hline Sample & Plant species & $\begin{array}{l}\text { Closest related virus or viroid sequence (genus or } \\
\text { family) }\end{array}$ & $\begin{array}{l}\text { \% identity, } \\
\text { longest hit length }\end{array}$ \\
\hline HBZ-15 & Cleome & $\begin{array}{l}\text { Tobacco ringspot virus (Nepovirus) } \\
\text { Tulip virus X (Potexvirus) }\end{array}$ & $\begin{array}{l}96 \%, 2524 \mathrm{nt} \\
100 \%, 5679 \mathrm{nt}\end{array}$ \\
\hline HBZ-16 & Verbena & Angelonia flower break virus (Carmovirus) & $98 \%, 1948 \mathrm{nt}$ \\
\hline HBZ-17 & Wild sweetpea & $\begin{array}{l}\text { Pea enation virus (Enamovirus) } \\
\text { Prune dwarf virus (Ilarvirus) } \\
\text { Tobacco streak virus (Ilarvirus) } \\
\text { Viola white distortion-associated virus (Ilarvirus) } \\
\text { Fragaria chiloensis latent virus (Ilarvirus) } \\
\text { Bean leafroll virus (Luteovirus) } \\
\text { Citrus vein enation virus (Luteovirus) } \\
\text { Rose spring dwarf virus (Luteovirus) } \\
\text { Soybean dwarf virus (Luteovirus) }\end{array}$ & $\begin{array}{l}93 \%, 337 \mathrm{nt} \\
89 \%, 411 \mathrm{nt} \\
88 \%, 81 \mathrm{nt} \\
96 \%, 126 \mathrm{nt} \\
100 \%, 112 \mathrm{nt} \\
79 \%, 163 \mathrm{nt} \\
93 \%, 167 \mathrm{nt} \\
77 \%, 368 \mathrm{nt} \\
72 \%, 437 \mathrm{nt}\end{array}$ \\
\hline HBZ-18 & Cineraria & Tomato spotted wilt virus (Tospovirus) & $100 \%, 583 \mathrm{nt}$ \\
\hline HBZ-19 & Asclepias & Citrus endogenous virus (Pararetrovirus)s & $96 \%, 102 \mathrm{nt}$ \\
\hline HBZ-20 & Carnation & $\begin{array}{l}\text { Dianthus caryophyllus viroid-like DNA } \\
\text { Fig cryptic virus virus (Deltapartitivirus) }\end{array}$ & $\begin{array}{l}99 \%, 131 \mathrm{nt} \\
79 \%, 176 \mathrm{nt}\end{array}$ \\
\hline HBZ-21 & Anemone & $\begin{array}{l}\text { Blueberry latent virus (Amalgavirus) } \\
\text { Raphanus sativus cryptic virus } 3 \text { (Deltapartitivirus) } \\
\text { Oryza sativa virus (Endornavirus) } \\
\text { Yerba mate virus (Endornavirus) } \\
\text { Vicia faba virus (Partitiviridae) }\end{array}$ & $\begin{array}{l}93 \%, 115 \mathrm{nt} \\
93 \%, 107 \mathrm{nt} \\
96 \%, 87 \mathrm{nt} \\
96 \%, 70 \mathrm{nt} \\
93 \%, 146 \mathrm{nt}\end{array}$ \\
\hline HBZ-22 & Petunia & Petunia vein clearing virus (Badnavirus) & $100 \%, 172 \mathrm{nt}$ \\
\hline HBZ-23 & Lisianthus & Eggplant mottled dwarf virus (Rhabdovirus) & $100 \%, 2149 \mathrm{nt}$ \\
\hline HBZ-24 & Squash & Carrot torrado virus (Torradovirus) & $73 \%, 831 \mathrm{nt}$ \\
\hline
\end{tabular}

Highlighted viruses considered to be identified with certainty to species level: in red if scaffolds $>500$ $\mathrm{pb}$ and $>95 \%$ identity, in green if integrated in the host genome. 
Table 4 Pilot study: Analysis of viral scaffolds and remainder contigs of pooled samples

\begin{tabular}{llll}
\hline $\begin{array}{l}\text { Pool } \\
\text { composition }\end{array}$ & $\begin{array}{l}\text { RNA } \\
\text { extraction } \\
\text { and } \\
\text { sequencing } \\
\text { strategy }\end{array}$ & $\begin{array}{l}\text { Viruses that should be present (sum of } \\
\text { viruses in individual samples) }\end{array}$ & Viruses not detected \\
& \\
\hline
\end{tabular}

$\begin{array}{ll}\text { HBZ-11 } & \text { HBZ-15 } \\ & \text { HBZ-16 } \\ & \text { HBZ-17 } \\ & \text { HBZ-18 } \\ & \\ & \\ \text { HBZ-13 } & \text { HBZ-15 } \\ & \text { HBZ-16 } \\ & \text { HBZ-17 } \\ & \text { HBZ-18 } \\ \text { HBZ-19 }\end{array}$

HBZ-25 HBZ-15

HBZ-16

HBZ-17

HBZ-18

HBZ-19
2

\author{
Angelonia flower break virus (Carmovirus) \\ Tobacco ringspot virus (Nepovirus) \\ Tomato spotted wilt virus (Tospovirus) \\ Tulip virus X (Potexvirus) \\ Enamovirus \\ Luteovirus \\ Ilarvirus \\ Pararetrovirus
}

3
Angelonia flower break virus (Carmovirus)
Tobacco ringspot virus (Nepovirus)
Tomato spotted wilt virus (Tospovirus)
Tulip virus X (Potexvirus)
Enamovirus
Luteovirus
Ilarvirus
Pararetrovirus

4
Angelonia flower break virus (Carmovirus)
Tobacco ringspot virus (Nepovirus)
Tomato spotted wilt virus (Tospovirus)
Tulip virus X (Potexvirus)
Enamovirus
Luteovirus
Ilarvirus
Pararetrovirus

$\begin{array}{llll}\text { HBZ-12 } & \text { HBZ-20 } & 2 & \begin{array}{l}\text { Eggplant mottled dwarf virus (Rhabdovirus) } \\ \text { Dianthus caryophyllus } \text { viroid-like DNA }\end{array} \\ \text { HBZ-21 } & & \begin{array}{l}\text { Petunia vein clearing virus (Badnavirus) } \\ \text { TBZ-22 } \\ \text { HBZ-23 } \\ \text { HBZ-24 }\end{array} \\ \text { dsRNA virus }\end{array}$

Enamovirus

Pararetrovirus

Enamovirus

Pararetrovirus

Enamovirus

Pararetrovirus
Petunia vein clearing virus (Badnavirus) dsRNA virus

Petunia vein clearing virus (Badnavirus) dsRNA virus

Petunia vein clearing virus (Badnavirus) dsRNA virus

Highlighted viruses considered to be identified with certainty to species level: in red if scaffolds $>500$ $\mathrm{pb}$ and $>95 \%$ identity, in green if integrated in the host genome. 
Table 5 (suppl) Full-scale study: Quality of de novo assembly of contigs and scaffolds in Matrix 3

\begin{tabular}{|c|c|c|c|c|c|c|c|c|c|}
\hline \multirow[b]{2}{*}{ Sample } & \multirow[b]{2}{*}{$\begin{array}{l}21-24 n t \\
\text { reads } \\
\left(10^{6}\right)\end{array}$} & \multicolumn{4}{|c|}{ Contigs $^{I}$} & \multicolumn{4}{|c|}{ Scaffolds $^{I}$} \\
\hline & & N50 & $\begin{array}{l}\text { Maximum } \\
\text { length }\end{array}$ & $\begin{array}{l}\text { Average } \\
\text { length }\end{array}$ & $\begin{array}{l}\text { Total } \\
\text { length }\end{array}$ & N50 & $\begin{array}{l}\text { Maximum } \\
\text { length }\end{array}$ & $\begin{array}{l}\text { Average } \\
\text { length }\end{array}$ & $\begin{array}{l}\text { Total } \\
\text { length }\end{array}$ \\
\hline HBZ-47 & 4.9 & 416 & 3085 & 281 & 76064 & 733 & 5036 & 462 & 72119 \\
\hline HBZ-48 & 3.8 & 504 & 2863 & 300 & 36220 & 1124 & 2863 & 482 & 31309 \\
\hline HBZ-51 & 2.5 & 183 & 913 & 190 & 31680 & 340 & 1152 & 277 & 22425 \\
\hline HBZ-52 & 3.9 & 525 & 2047 & 322 & 38981 & 900 & 4118 & 531 & 34540 \\
\hline HBZ-53 & 4.0 & 481 & 3474 & 294 & 51271 & 1277 & 3887 & 535 & 39605 \\
\hline HBZ-54 & 3.3 & 231 & 1100 & 214 & 31289 & 363 & 1100 & 305 & 25310 \\
\hline HBZ-55 & 5.5 & 470 & 3944 & 302 & 58948 & 879 & 4465 & 506 & 52573 \\
\hline HBZ-64 & 6.2 & 792 & 4581 & 320 & 41426 & 1439 & 6063 & 530 & 30227 \\
\hline HBZ-65 & 7.5 & 296 & 3426 & 265 & 31929 & 690 & 4259 & 471 & 24498 \\
\hline HBZ-66 & 1.8 & 193 & 1714 & 194 & 13585 & 304 & 2087 & 292 & 10800 \\
\hline
\end{tabular}

${ }^{1}$ All lengths in nucleotides

Table 6 Full-scale study: Matrix 3, overview of yield

\begin{tabular}{|c|c|c|c|c|c|c|c|c|}
\hline Pool & $\begin{array}{l}\text { Number } \\
\text { scaffolds }\end{array}$ & $\begin{array}{l}E> \\
10^{-5}\end{array}$ & NSS & $\begin{array}{l}\text { Number } \\
\text { viral } \\
\text { scaffolds }\end{array}$ & $\begin{array}{l}\text { Number } \\
\text { remainders }\end{array}$ & $\begin{array}{l}E> \\
10^{-5}\end{array}$ & NSS & $\begin{array}{l}\text { Number } \\
\text { viral } \\
\text { remainders }\end{array}$ \\
\hline HBZ-47 & 156 & 20 & 2 & 103 & 114 & 38 & 1 & 27 \\
\hline HBZ-48 & 65 & 7 & 1 & 31 & 74 & 24 & 0 & 29 \\
\hline HBZ-51 & 81 & 4 & 0 & 41 & 86 & 15 & 0 & 18 \\
\hline HBZ-52 & 65 & 8 & 0 & 35 & 52 & 19 & 0 & 6 \\
\hline HBZ-53 & 74 & 18 & 0 & 23 & 117 & 45 & 1 & 5 \\
\hline HBZ-54 & 83 & 2 & 0 & 49 & 65 & 9 & 0 & 23 \\
\hline HBZ-55 & 104 & 10 & 0 & 79 & 97 & 52 & 1 & 31 \\
\hline HBZ-64 & 57 & 15 & 1 & 12 & 103 & 45 & 2 & 1 \\
\hline HBZ-65 & 52 & 7 & 0 & 18 & 82 & 37 & 0 & 7 \\
\hline HBZ-66 & 37 & 4 & 1 & 0 & 33 & 17 & 0 & 1 \\
\hline Totals & 774 & 95 & 5 & 391 & 823 & 301 & 5 & 148 \\
\hline
\end{tabular}

Sequences are considered viral if $E<10^{-5}$ to a viral sequence identified by CLC BlastN at NCBI. NSS: no significant similarity ("not available" according to CLC Workbench)

$12.3 \%$ scaffolds and $36.6 \%$ remainders had $E>10^{-5}$ 
Table 7 Full-scale study: Viral sequences identified in Matrix 3 pools

\begin{tabular}{|c|c|c|c|}
\hline Pool & Known viral species present ${ }^{1}$ & $\begin{array}{l}\text { Genera to which } \\
\text { new viral species } \\
\text { belong }{ }^{2}\end{array}$ & $\begin{array}{l}\text { Viral presence shown from } \\
\text { mapping reads on scaffolds and } \\
\text { contigs }\end{array}$ \\
\hline HBZ-47 & $\begin{array}{ll}\text { - } & \text { Bean yellow mosaic virus } \\
\text { - } & \text { Canna yellow streak virus } \\
\text { - } & \text { Ranunculus mild mosaic virus } \\
\text { - } & \text { Tobacco rattle virus } \\
\text { Tomato spotted wilt virus }\end{array}$ & $\begin{array}{ll}- & \text { Potyvirus } \\
- & \text { Badnavirus }\end{array}$ & $\begin{array}{ll}\text { HBZ-47 reads mapped on } \\
\text { potyvirus of HBZ-53 } \\
\text { HBZ-47 reads mapped on } \\
\text { potyvirus of HBZ-55 }\end{array}$ \\
\hline HBZ-48 & $\begin{array}{l}\text { - Cycas necrotic stunt virus } \\
\text { - } \quad \text { Tomato spotted wilt virus }\end{array}$ & - Nepovirus & $\bullet$ \\
\hline HBZ-51 & $\begin{array}{ll}\text { - } & \text { Alstroemeria mosaic virus } \\
\text { - } & \text { Lily symptomless virus } \\
\text { - } & \text { Tobacco rattle virus } \\
\text { - } & \text { Tobacco ringspot virus } \\
\end{array}$ & - $\quad$ Potyvirus & $\begin{array}{ll}\text { HBZ-51 reads mapped on } \\
\text { Alstroemeria mosaic of HBZ-52 } \\
\text { HBZ-51 reads mapped on } \\
\text { potyvirus of HBZ-52 }\end{array}$ \\
\hline HBZ-52 & $\begin{array}{l}\text { - Impatiens necrotic spot virus } \\
\text { - } \quad \text { Ranunculus leaf distortion virus }\end{array}$ & $\begin{array}{ll}\text { - } & \text { Partitivirus } \\
\text { - } & \text { Potyvirus }\end{array}$ & $\begin{array}{ll}\text { - } & \text { HBZ-52 reads mapped on } \\
\text { Alstroemeria mosaic of HBZ-51 } \\
\text { - } & \text { HBZ-52 reads mapped on Lily } \\
\text { symptomless of HBZ-51 } \\
\text { - } \\
\text { HBZ-52 reads mapped on } \\
\text { potyvirus of HBZ-65 }\end{array}$ \\
\hline HBZ-53 & $\begin{array}{ll} & \text { Petunia vein clearing virus } \\
\text { - } & \text { Ranunculus mild mosaic virus } \\
\text { - } & \text { Tomato spotted wilt virus } \\
\end{array}$ & - $\quad$ Potyvirus & $\begin{array}{l}\text { HBZ-53 reads mapped on } \\
\text { potyvirus of HBZ-47 }\end{array}$ \\
\hline HBZ-54 & $\begin{array}{ll}\text { - } & \text { Cycas necrotic stunt virus } \\
\text { - } & \text { Tobacco rattle virus } \\
\text { - } & \text { Tobacco ringspot virus } \\
\end{array}$ & - Nepovirus & $\begin{array}{l}\text { - HBZ-54 reads mapped on } \\
\text { potyvirus of HBZ-47 }\end{array}$ \\
\hline HBZ-55 & $\begin{array}{l}\text { - } \quad \text { Bean yellow mosaic virus } \\
\text { - } \quad \text { Canna yellow streak virus } \\
\text { - } \quad \text { Cycas necrotic stunt virus } \\
\text { - } \quad \text { Tomato spotted wilt virus } \\
\end{array}$ & $\begin{array}{ll}- & \text { Badnavirus } \\
\text { - } & \text { Nepovirus } \\
\text { - } & \text { Potyvirus }\end{array}$ & $\begin{array}{l}\text { HBZ-55 reads mapped on } \\
\text { potyvirus of HBZ-47 }\end{array}$ \\
\hline HBZ-64 & - Impatiens necrotic spot virus & - $\quad$ Partitivirus & \\
\hline HBZ-65 & $\begin{array}{l}\text { - } \quad \text { Petunia vein clearing virus } \\
\text { - } \quad \text { Ranunculus leaf distortion virus }\end{array}$ & - Potyvirus & $\begin{array}{l}\text { - } \quad \begin{array}{l}\text { HBZ-65 reads mapped on } \\
\text { potyvirus of HBZ-52 }\end{array} \\
\end{array}$ \\
\hline HBZ-66 & & - Ilarvirus & $\begin{array}{ll} & \begin{array}{l}\text { HBZ-66 reads mapped on } \\
\text { potyvirus of HBZ-65 }\end{array} \\
\end{array}$ \\
\hline
\end{tabular}

${ }^{1}$ Identified to species if there are scaffolds or contigs with $>100 \mathrm{nt}$ having $>90 \%$ identity to the sequence of a known virus. ${ }^{2}$ Identified to genus if there are scaffolds or contigs with $>100 \mathrm{nt}$ having $<90 \%$ identity to a viral sequence, and $\mathrm{E}<10^{-5}$. 
Table 8 Confirmation of the presence of specific viral sequences by RT-PCR

\begin{tabular}{llllcc}
\hline Sample & $\begin{array}{l}\text { Plant } \\
\text { species }\end{array}$ & Study & Virus species or genus & $\begin{array}{c}\text { \% identity } \\
\text { to reference }\end{array}$ & $\begin{array}{l}\text { PCR product } \\
\text { length (nt) }\end{array}$ \\
\hline V033 & Kalanchoe & Matrix 2 & Kalanchoe mosaic virus & 97 & 824 \\
\hline V057 & Banana & Matrix 2 & Banana mild mosaic virus & 100 & 74 \\
\hline V082 & Iris & Matrix 2 & Iris mild mosaic virus & 97 & 819 \\
\hline V082 & Iris & Matrix 2 & Ornithogalum mosaic virus & 98 & 455 \\
\hline V090 & Buttercup & Matrix 3 & Ranunculus leaf distortion virus & 99 & 814 \\
\hline V090 & Buttercup & Matrix 3 & Potyvirus & 72 & 482 \\
\hline V090 & Buttercup & Matrix 3 & Potyvirus & 79 & 479 \\
\hline V095 & Buttercup & Matrix 3 & Ranunculus mild mosaic virus & 95 & 58 \\
\hline V095 & Buttercup & Matrix 3 & Potyvirus & 70 & 470 \\
\hline V095 & Buttercup & Matrix 3 & Tomato spotted wilt virus & 99 & 811 \\
\hline V098 & Alstroemeria & Matrix 3 & Alstroemeria mosaic virus & 93 & 60 \\
\hline V098 & Alstroemeria & Matrix 3 & Potyvirus & 72 & 233 \\
\hline V102 & Petunia & Matrix 3 & Potyvirus & 68 & 640 \\
\hline V114 & Lisianthus & Pilot & Eggplant mottled dwarf virus & 97 & 435 \\
\hline V116 & Peony & Matrix 3 & Tobacco rattle virus & 99 & 347 \\
\hline V132 & Canna & Matrix 3 & Bean yellow mosaic virus & 86 & 363 \\
\hline
\end{tabular}

RT-PCR was carried out with primers specific to the scaffold or remainder contig to be confirmed.

Table 9 Pilot and full-scale study: Types of viruses and viroids detected

\begin{tabular}{|c|c|c|}
\hline Type of pathogen & Number of genera & Genera (number of species) observed \\
\hline (+) ssRNA virus & 15 & $\begin{array}{l}\text { Carlavirus (1), Carmovirus (1), Closterovirus (1), } \\
\text { Cucumovirus (1), Enamovirus (1), Ilarvirus (2), } \\
\text { Luteovirus (1), Nepovirus (2), Polerovirus (2), } \\
\text { Potexvirus (1), Potyvirus (13), Tobravirus (1), } \\
\text { Tombusvirus (2), Torradovirus (1), Unassigned } \\
\text { Betaflexiviridae (1) }\end{array}$ \\
\hline (-) ssRNA virus & 2 & Rhabdovirus (1), Tospovirus (2) \\
\hline dsRNA virus & 3 & Amalgavirus (1), Endornavirus (2), Partitivirus (3) \\
\hline $\begin{array}{l}\text { dsDNA virus } \\
\text { (including EPRVs) }\end{array}$ & 3 & $\begin{array}{l}\text { Badnavirus (4), Caulimovirus (2), endogenous } \\
\text { pararetrovirus (1) }\end{array}$ \\
\hline SsDNA virus & 1 & Begomovirus (1) \\
\hline Viroid & 1 & Hostuviroid (1), Viroid-like DNA (1) \\
\hline Total & 25 & 50 \\
\hline
\end{tabular}


Table 10 (suppl) Pilot and Full-scale study: Complete compilation of viral/viroid sequences observed

\begin{tabular}{|c|c|c|c|c|}
\hline Sample & Species & Study & Virus/viroid sequence identified (acronym) & Genus \\
\hline V003 & Cleome & Pilot & Tobacco ringspot virus (TRSV) & Nepovirus \\
\hline V003 & Cleome & Pilot & Tulip virus X (TVX) & Potexvirus \\
\hline V012 & Verbena & Pilot & Angelonia flower break virus (AnFBV) & Carmovirus \\
\hline V036 & Wild sweetpea & Pilot & Ilarvirus & Ilarvirus \\
\hline V036 & Wild sweetpea & Pilot & Enamovirus & Enamovirus \\
\hline V036 & Wild sweetpea & Pilot & Allexivirus & Allexivirus \\
\hline V036 & Wild sweetpea & Pilot & Luteovirus & Luteovirus \\
\hline V054 & Cineraria & Pilot & Tomato spotted wilt virus (TSWV) & Tospovirus \\
\hline V054 & Cineraria & Pilot & Soymovirus & Soymovirus \\
\hline V074 & Asclepias & Pilot & Pararetrovirus & Pararetrovirus \\
\hline V077 & Carnation & Pilot & Dianthus caryophyllus viroid-like DNA (CarSAVd) & Viroid-like DNA \\
\hline V077 & Carnation & Pilot & Deltapartitivirus & Deltapartitivirus \\
\hline V101 & Anemone & Pilot & Deltapartitivirus & Deltapartitivirus \\
\hline V101 & Anemone & Pilot & Amalgavirus & Amalgavirus \\
\hline V101 & Anemone & Pilot & Endornavirus & Endornavirus \\
\hline V104 & Petunia & Pilot & Petunia vein clearing virus (PVCV) & Badnavirus \\
\hline V114 & Lisianthus & Pilot & Eggplant mottled dwarf virus (EMDV) & Rhabdovirus \\
\hline V142 & Squash & Pilot & Squash chlorotic leaf spot virus (SCLSV) & Torradovirus \\
\hline V004 & Verbena & Matrix 1 & Angelonia flower break virus (AnFBV) & Carmovirus \\
\hline V005 & Primrose & Matrix 1 & none & \\
\hline V009 & Geranium & Matrix 1 & Pelargonium flower break virus (PFBV) & Carmovirus \\
\hline V009 & Geranium & Matrix 1 & Pelargonium line pattern virus (PLPV) & Tombusvirus \\
\hline V009 & Geranium & Matrix 1 & Pelargonium vein banding virus (PVBV) & Badnavirus \\
\hline V020 & phlox & Matrix 1 & none & \\
\hline V021 & Cleome & Matrix 1 & Cucumber mosaic virus + satRNA (CMV) & Cucumovirus \\
\hline V022 & Carnation & Matrix 1 & Carnation etched ring virus (CERV) & Caulimovirus \\
\hline V022 & Carnation & Matrix 1 & Tomato spotted wilt virus (TSWV)? & Tospovirus \\
\hline V026 & Geranium & Matrix 1 & Pelargonium flower break virus (PFBV) & Carmovirus \\
\hline V026 & Geranium & Matrix 1 & Pelargonium vein banding virus (PVBV) & Badnavirus \\
\hline V026 & Geranium & Matrix 1 & Tomato spotted wilt virus (TSWV)? & Tospovirus \\
\hline V029 & NG Impatiens & Matrix 1 & Impatiens necrotic spot virus (INSV) & Tospovirus \\
\hline V029 & NG Impatiens & Matrix 1 & Tomato spotted wilt virus (TSWV)? & Tospovirus \\
\hline V031 & Verbena & Matrix 1 & Tomato spotted wilt virus (TSWV)? & Tospovirus \\
\hline V119 & Lisianthus & Matrix 1 & none & \\
\hline V146 & Violet & Matrix 1 & Viola white distortion associated virus (VWDaV) & Ilarvirus \\
\hline V027 & Geranium & Matrix 2 & Pelargonium vein banding virus (PVBV) & Badnavirus \\
\hline V032 & Hydrangea & Matrix 2 & Potyvirus? & Potyvirus \\
\hline
\end{tabular}




\begin{tabular}{|c|c|c|c|c|}
\hline V033 & Kalanchoe & Matrix 2 & Impatiens necrotic spot virus (INSV) & Tospovirus \\
\hline V033 & Kalanchoe & Matrix 2 & Kalanchoe mosaic virus (KMV) & Potyvirus \\
\hline V033 & Kalanchoe & Matrix 2 & Potyvirus & Potyvirus \\
\hline V033 & Kalanchoe & Matrix 2 & Rhabdovirus & Rhabdovirus \\
\hline V035 & Lilac & Matrix 2 & Caulimovirus & Caulimovirus \\
\hline V035 & Lilac & Matrix 2 & Begomovirus & Begomovirus \\
\hline V037 & Periwinkle & Matrix 2 & Endornavirus & Endornavirus \\
\hline V037 & Periwinkle & Matrix 2 & Polerovirus & Polerovirus \\
\hline V039 & NG impatiens & Matrix 2 & Tomato spotted wilt virus (TSWV)? & Tospovirus \\
\hline V046 & Dahlia & Matrix 2 & Dahlia latent viroid (DLVd) & Viroid \\
\hline V046 & Dahlia & Matrix 2 & Dahlia mosaic virus (DMV) & Caulimovirus \\
\hline V046 & Dahlia & Matrix 2 & Tomato spotted wilt virus (TSWV)? & Tospovirus \\
\hline V047 & Centranthus & Matrix 2 & Caulimovirus & Caulimovirus \\
\hline V048 & Oleander & Matrix 2 & none & \\
\hline V051 & Chrysanthemum & Matrix 2 & Potyvirus? & Potyvirus \\
\hline V051 & Chrysanthemum & Matrix 2 & Tomato spotted wilt virus (TSWV)? & Tospovirus \\
\hline V055 & Velvet leaf & Matrix 2 & Tomato spotted wilt virus (TSWV) & Tospovirus \\
\hline V055 & Velvet leaf & Matrix 2 & viroid & Viroid \\
\hline V057 & Banana & Matrix 2 & Banana mild mosaic virus (BanMMV) & Betaflexiviridae \\
\hline V057 & Banana & Matrix 2 & Banana streak virus (BSV) & Badnavirus \\
\hline V062 & Pomelo & Matrix 2 & Citrus tristeza virus (CTV) & Closterovirus \\
\hline V062 & Pomelo & Matrix 2 & Pararetrovirus & Pararetrovirus \\
\hline V063 & Cyclamen & Matrix 2 & Tomato spotted wilt virus (TSWV)? & Tospovirus \\
\hline V063 & Cyclamen & Matrix 2 & Potyvirus & Potyvirus \\
\hline V068 & Alstroemeria & Matrix 2 & Tomato spotted wilt virus (TSWV)? & Tospovirus \\
\hline V069 & Hydrangea & Matrix 2 & none & \\
\hline V072 & Lily & Matrix 2 & none & \\
\hline V082 & Iris & Matrix 2 & Iris mild mosaic virus (IMMV) & Potyvirus \\
\hline V082 & Iris & Matrix 2 & Ornithogalum mosaic virus (OrMV) & Potyvirus \\
\hline V082 & Iris & Matrix 2 & Polerovirus & Polerovirus \\
\hline V082 & Iris & Matrix 2 & Potyvirus & Potyvirus \\
\hline V082 & Iris & Matrix 2 & Tomato spotted wilt virus (TSWV)? & Tospovirus \\
\hline V084 & Green bell & Matrix 2 & Potyvirus? & Potyvirus \\
\hline V084 & Green bell & Matrix 2 & Tomato spotted wilt virus (TSWV) & Tospovirus \\
\hline V087 & Snapdragon & Matrix 2 & Tomato spotted wilt virus (TSWV)? & Tospovirus \\
\hline V001 & Petunia & Matrix 3 & none & \\
\hline V085 & Guzmania & Matrix 3 & Potyvirus? & Potyvirus \\
\hline V086 & Draceana & Matrix 3 & none & \\
\hline V088 & Anemone & Matrix 3 & Impatiens necrotic spot virus (INSV) & Tospovirus \\
\hline V088 & Anemone & Matrix 3 & Partitivirus & Partitivirus \\
\hline V089 & Anemone & Matrix 3 & Potyvirus & Potyvirus \\
\hline V090 & Buttercup & Matrix 3 & Potyvirus (may be rest of RanLDV) & Potyvirus \\
\hline V090 & Buttercup & Matrix 3 & Ranunculus leaf distortion virus (RanLDV) & Potyvirus \\
\hline V095 & Buttercup & Matrix 3 & Potyvirus (may be rest of RanMMV) & Potyvirus \\
\hline
\end{tabular}




\begin{tabular}{|c|c|c|c|c|}
\hline V095 & Buttercup & Matrix 3 & Ranunculus mild mosaic virus (RanMMV) & Potyvirus \\
\hline V095 & Buttercup & Matrix 3 & Tomato spotted wilt virus (TSWV) & Tospovirus \\
\hline V098 & Alstroemeria & Matrix 3 & Alstroemeria mosaic virus (AlMV) & Potyvirus \\
\hline V098 & Alstroemeria & Matrix 3 & Lily symptomless virus (LSV) & Carlavirus \\
\hline V098 & Alstroemeria & Matrix 3 & Potyvirus (may be rest of AlMV) & Potyvirus \\
\hline V099 & Primrose & Matrix 3 & Tomato spotted wilt virus (TSWV) & Tospovirus \\
\hline V100 & Geranium & Matrix 3 & none & \\
\hline V102 & Petunia & Matrix 3 & Petunia vein clearing virus (PVCV) & Badnavirus \\
\hline V102 & Petunia & Matrix 3 & Potyvirus & Potyvirus \\
\hline V106 & Dicentra & Matrix 3 & Potyvirus? & Potyvirus \\
\hline V116 & Peony & Matrix 3 & Potyvirus? & Potyvirus? \\
\hline V116 & Peony & Matrix 3 & Tobacco rattle virus (TRV) & Tobravirus \\
\hline V116 & Peony & Matrix 3 & Viroid-like DNA & Viroid-like DNA \\
\hline V118 & Peony & Matrix 3 & Cycas necrotic stunt virus & Nepovirus \\
\hline V118 & Peony & Matrix 3 & Tomato spotted wilt virus (TSWV)? & Tospovirus \\
\hline V120 & Snapdragon & Matrix 3 & Cycas necrotic stunt virus (CNSV) & Nepovirus \\
\hline V122 & Lisianthus & Matrix 3 & none & \\
\hline V124 & Hibiscus & Matrix 3 & none & \\
\hline V129 & Cleome & Matrix 3 & Tobacco rattle virus (TRV) & Tobravirus \\
\hline V129 & Cleome & Matrix 3 & Tobacco ringspot virus (TRSV) & Nepovirus \\
\hline V132 & Canna & Matrix 3 & Badnavirus & Badnavirus \\
\hline V132 & Canna & Matrix 3 & Bean yellow mosaic virus (BYMV) & Potyvirus \\
\hline V132 & Canna & Matrix 3 & Canna yellow streak virus (CaYSV) & Potyvirus \\
\hline V132 & Canna & Matrix 3 & Potyvirus & Potyvirus? \\
\hline V132 & Canna & Matrix 3 & Tomato spotted wilt virus (TSWV)? & Tospovirus \\
\hline V133 & Chrysanthemum & Matrix 3 & none & \\
\hline V134 & Tea & Matrix 3 & Potyvirus & Potyvirus \\
\hline V137 & Pansy & Matrix 3 & Potyvirus? & Potyvirus \\
\hline V139 & Daisy & Matrix 3 & Ilarvirus & Ilarvirus \\
\hline V141 & Holly & Matrix 3 & none & \\
\hline V145 & Wild tulip & Matrix 3 & none & \\
\hline
\end{tabular}


Table 11 Pilot and full-scale study: Previously undescribed pathogen sequences detected

\begin{tabular}{lll}
\hline Type of pathogen & Host plant & Viral genus \\
\hline (+) ssRNA virus & Hydrangea & Potyvirus \\
& Periwinkle & Polerovirus \\
& Iris & Polerovirus \\
& Ranunculus & Potyvirus \\
& Canna & Potyvirus \\
& Daisy & Ilarvirus \\
& Anemone & Potyvirus \\
& Wild sweetpea & Luteovirus \\
& Wild sweetpea & Ilarvirus \\
& Squash & Torradovirus \\
\hline (-) ssRNA virus & Kalanchoe & Rhabdovirus \\
\hline dsRNA virus & Periwinkle & Endornavirus \\
& Anemone & Partitivirus \\
& Carnation & Partitivirus \\
& Anemone & Partitivirus \\
& Anemone & Endornavirus \\
& Anemone & Amalgavirus \\
\hline dsDNA virus & Centranthus & Caulimovirus \\
(including EPRVs) & Pomelo & Pararetrovirus (endogenous?) \\
& Lilac & Caulimovirus \\
& Canna & Badnavirus \\
& Asclepias & Pararetrovirus (endogenous?) \\
\hline ssDNA virus & Lilac & Begomovirus \\
\hline Viroid & Abutilon & Hostuviroid \\
& Peony & Viroid-like RNA \\
\hline & & \\
\hline
\end{tabular}

Table 12 Pilot and full-scale study: New hosts of previously described viruses

\begin{tabular}{llll}
\hline Sample & Host plant & Virus identified & Genus \\
\hline & & & \\
\hline V003 & Cleome & Tobacco ringspot virus (TRSV) & Nepovirus \\
\hline V003 & Cleome & Tulip virus X (TVX) & Potexvirus \\
\hline V114 & Lisianthus & Eggplant mottled dwarf virus (EMDV) & Rhabdovirus \\
\hline V055 & Velvet leaf & Tomato spotted wilt virus (TSWV) & Tospovirus \\
\hline
\end{tabular}

